\title{
Chemical characterization and relative toxicity assessment of disinfection byproduct mixtures in a large drinking water supply network
}

\author{
Cristina Postigo $^{(1),{ }^{*}}$, Pere Emiliano ${ }^{(2)}$, Damià Barceló ${ }^{(1,3)}$, Fernando Valero ${ }^{(2)}$, \\ (1) Institute for Environmental Assessment and Water Research (IDAEA-CSIC), \\ Barcelona, Spain. \\ (2) ATLL CGCSA, Sant Martí de l'Erm, 30, 08970 Sant Joan Despí, Barcelona, \\ Spain \\ (3) Catalan Institute for Water Research (ICRA), Girona, Spain.
}

*cprqam@ cid.csic.es, Tel: +34-934-006-100, Fax: +34-932-045-904

\begin{abstract}
Reducing the formation of disinfection by-products (DBPs) during the process of water potabilization and proper risk assessment of drinking water requires exploring the potential of the source water and the applied treatment to generate these chemicals. This is actually more challenging in large drinking water networks that use different source waters to satisfy potable water demand. In this regard, this works investigated the formation of DBPs in water matrices that are commonly supplied to the city of Barcelona and its metropolitan area. The regulated trihalomethanes and haloacetic acids were the most abundant DBP classes in these waters, followed by haloacetamides and haloacetonitriles or trihalogenated acetaldehydes (THALs). On the contrary, the formation potential of iodo-DBPs was minor. Mixing of drinking water treatment plant (DWTP) finished waters with desalinated water decreased the overall DBP formation potential of the water but resulted in the increased formation of brominated DBPs after long chlorine contact time. The formation of most DBPs was enhanced at high water temperatures (except for Br-THALs) and increasing residence times. Potential cytotoxicity and genotoxicity of the DBP mixtures were mainly attributed to the presence of nitrogen-containing DBPs and HAAs.
\end{abstract}

Keywords iodinated disinfection by-products, trihalomethanes, haloacetic acids, chlorination, drinking water treatment 


\section{Introduction}

Disinfection is an essential step in drinking water treatment processes all over the world to protect human health from waterborne diseases (amoebiasis, giardiasis, typhoid fever, dysentery, leptospirosis, cholera, etc). However, it is well known that disinfection using chemical agents results in the unintended formation of disinfection by-products (DBPs). Since the first discovery of this type of compounds in chlorinedisinfected water in the 70's [1,2], the formation of DBPs in disinfected water has become a matter of scientific concern. The toxicity exerted by some of them in model organisms has forced their inclusion in drinking water policies and guidelines. DBPs currently regulated in tap water in the USA are chlorinated and brominated trihalomethanes (THM4) $(80 \mu \mathrm{g} / \mathrm{L})$, bromate $(10 \mu \mathrm{g} / \mathrm{L})$, chlorite $(1 \mu \mathrm{mg} / \mathrm{L})$ and five haloacetic acids (HAA5) $(60 \mu \mathrm{g} / \mathrm{L})$ [3]. In the European Drinking Water Directive (DWD), maximum concentrations have been only set for THM4 $(100 \mu \mathrm{g} / \mathrm{L})$ and bromate $(10 \mu \mathrm{g} / \mathrm{L})[4]$.

DBP formation in disinfected water depends on the organic and inorganic DBP precursors present in the source water (i.e., natural and anthropogenic organic matter $(\mathrm{OM})$, and nitrogen, bromide and iodide content and/or sources) and the conditions under which the disinfection process is carried out (e.g., $\mathrm{pH}$, temperature, disinfectant dose, and disinfectant contact time) [5-8]. Thus, small changes in any of these aspects may have a severe impact on the suite of DBPs formed and consequently on the toxicity of the DBP mixture. In this regard, drinking water companies have put many efforts in the last two decades to investigate and document the THM formation potential of their source waters, so that the levels of these DBPs can be kept below the legally enforceable drinking water standards. This is the case of ATLL CGCSA, the water company in charge of treating and supplying potable water to more than 4.5 million people living in the city of Barcelona and its metropolitan area (northeast Spain).

The large drinking water supply system managed by ATLL CGCSA relies on the finished products of two drinking water treatment plants (DWTPs) and a seawater reverse-osmosis plant (SWRO). Research carried out on THMs in the past has led to upgrading water treatment to keep THM4 concentrations in the final product below regulatory limits, e.g., incorporation of electrodialysis reversal (EDR) in the DWTP 
that treats water with high bromide content due to upstream mining activities (Llobregat River water) since 2009. However, the potential of the source waters used to form unregulated (emerging) DBPs is still unknown. There is a need to fill in this gap of knowledge because the DWD is currently under revision and based on the available scientific evidence, additional DBPs, in particular, haloacetic acids (HAAs), may be regulated in the near future in Europe. Moreover, proper risk assessment of disinfected water requires considering not only THM4 but other DBPs that form during the disinfection process, and that are also known to be more toxic than regulated DBPs [8]. Despite the fact that toxicity effects of DBPs and DBP mixtures to human health are still largely unknown, many DBPs induced cytotoxic, neurotoxic, mutagenic, carcinogenic and teratogenic effects in in vitro toxicity studies [9], and several epidemiological studies have pointed out to a positive relation between THM4 exposure and bladder cancer incidence or the appearance of developmental and reproductive effects $[10,11]$.

In this context, the present work was carried out to investigate the potential of the water supplied to Barcelona and its metropolitan area to form several classes of DBPs and assess the comparative risk associated to these DBP mixtures. To fulfill this objective, DBP mixtures were chemically characterized in the final products of the DWTPs and the SWRO plant and their mixtures at different water temperatures and residence times. The list of investigated DBPs included emerging classes, i.e., iodinated trihalomethanes (I-THMs), trihalogenated haloacetaldehydes (THALs), halogenated acetonitriles (HANs), halogenated acetamides (HACMs), and HAAs, and regulated DBPs (THM4). To the authors' knowledge, this is the first time that a comprehensive study of the DBP mixtures present in such a large drinking water distribution system is carried out at Spanish and even at European level.

\section{Material and Methods}

\subsection{Drinking water supply network}

The investigated drinking water supply system covers, shown in Figure 1 is composed of two high capacity drinking water treatment plants (DWTP) (Llobregat DWTP and Ter DWTP), one medium capacity DWTP (Llosa del Cavall DWTP), and two seawater reverse osmosis (SWRO) desalination plants (Llobregat SWRO and Tordera SWRO). It covers an area of $450 \mathrm{~m}^{2}$ and supplies potable water to different 
municipalities and private water companies that manage supply local networks, serving up to 4.5 million inhabitants. ATLL CGCSA supply network has a total of 100 water tanks. The whole drinking water distribution network is satellite-controlled. This guarantees the coverage of drinking water demand and the quality of the final product. It uses Llobregat river water (Llobregat DWTP), Ter river water (Ter DWTP) and seawater (SWRO plant) as main source waters, and relies on chlorine as a final disinfectant

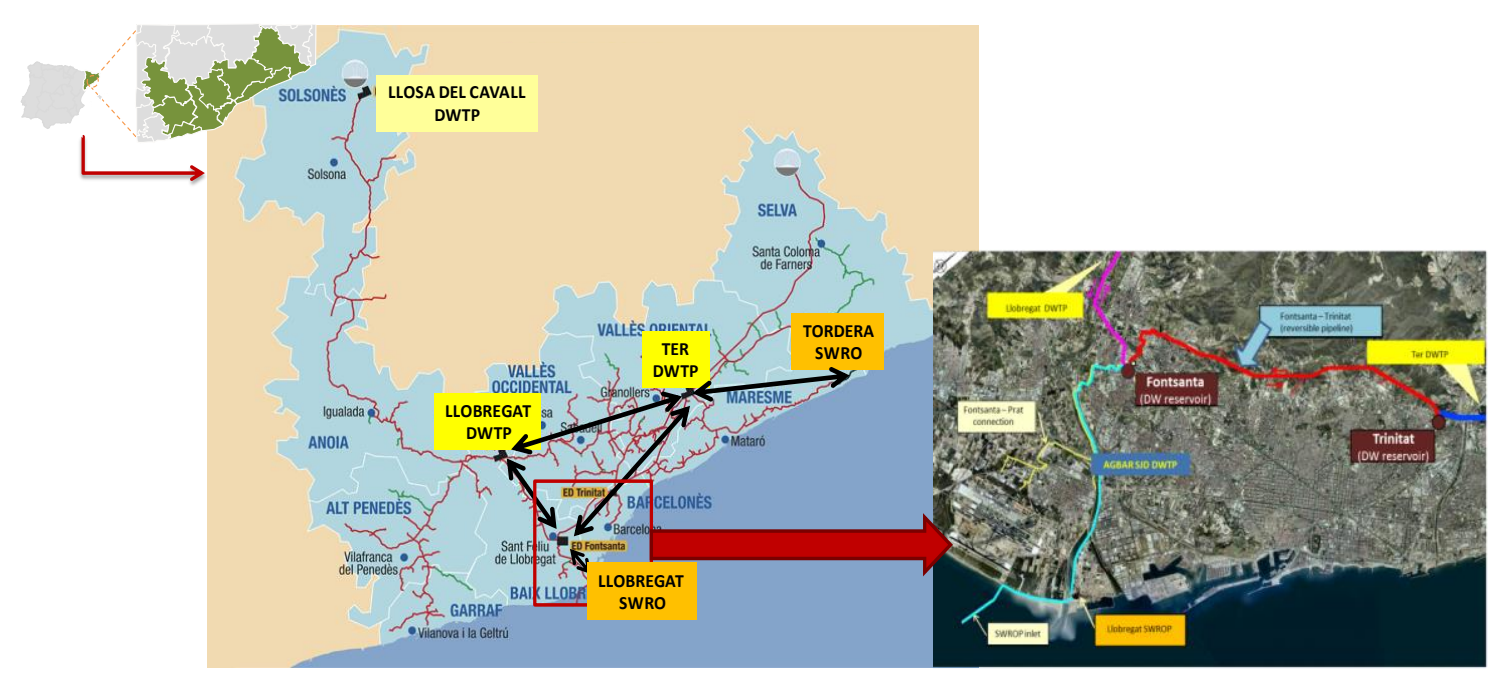

Figure 1. Scheme of the drinking water supply network of ATLL CGCSA.

The Llobregat DWTP has a conventional treatment capacity of $3.4 \mathrm{~m}^{3} / \mathrm{s}$ and a brackish water electrodialysis reversal (EDR) desalination capacity of $2.2 \mathrm{~m}^{3} / \mathrm{s}$. Water is diverted from the Llobregat River by means of a diversion dam and flows through a roughing screen to prevent large suspended materials from entering into the treatment system. Then, water flows through three sand trap channels and pre-oxidized with potassium permanganate. Water goes next through a coagulation-flocculation process based on aluminum polychloride, previous $\mathrm{pH}$ adjustment in a mixing chamber by means of carbon dioxide. Water then flows into 8 circular clarifiers. The clarified water flows out through radial channels and then is treated with chlorine dioxide. Disinfected water flows through $70 \mathrm{~cm}$-thick sand filters (unit area of $137 \mathrm{~m}^{2}$ ) and then through $150 \mathrm{~cm}$-thick carbon filters (unit volume of $150 \mathrm{~m}^{3}$ ). Part of the produced water goes through electrodialysis reversal (EDR) treatment to remove water salinity and improve both chemical and organoleptic qualities of water. EDR 
treated water is remineralized with lime. Potable water (disinfected with $\mathrm{NaOCl}$ ) is stored in four tanks $\left(263000 \mathrm{~m}^{3}\right.$ in total).

The Ter DWTP has a conventional treatment capacity of $8 \mathrm{~m}^{3} / \mathrm{s}$. It treats the water from an interconnected system of reservoirs (Sau, Susqueda and Pasteral) located in the Ter River. Water is diverted from the last dam, the Pasteral reservoir, into an underground gallery of $56 \mathrm{Km}$ and $3 \mathrm{~m}$ of diameter and transported by gravity into the DWTP. Firstly, water is treated with chlorine and chlorine dioxide, and then a coagulant (aluminum polychloride) is dosed for water clarification. These reagents are mixed with the water in two blending chambers and then water flows into eight clarifiers, where a flocculant is added. Next, clarified water passes through $80-\mathrm{cm}$ activated carbon filters (unit area $\left.91.2 \mathrm{~m}^{2}\right)$. Then, filtered water is chlorinated $\left(\mathrm{Cl}_{2}\right.$ gas) and stored in four tanks $\left(617000 \mathrm{~m}^{3}\right.$ in total).

T he Llobregat SWRO desalination plant has a treatment capacity of $2 \mathrm{~m}^{3} / \mathrm{s}$. Two towers located at $30 \mathrm{~m}$ depth and two pipes of $2.2 \mathrm{~km}$ length carry seawater to the pumping station located at the beach, which is $3 \mathrm{~km}$ away from the desalination plant. Before RO, seawater is pretreated by means of flotation-flocculation using ferric chloride as a coagulant and compressed air, gravity filtration through $1 \mathrm{~m}$-deep sand and anthracite multilayer filters, and closed filtration. Then, pretreated water goes through RO using high-pressure pumps (about 69 bars are required) and ten modules with seven membranes each. Each membrane has inside a spiral aromatic polyamide woven, and allows water to pass through. After RO, pure water is remineralized with the addition of carbon dioxide and making the water pass through a layer of calcite. Finally, the water is disinfected with $\mathrm{NaOCl}$ and pumped into storage tanks.

\subsection{DBP mixtures}

DBP formation potential was investigated in different water matrices: the finished water of the Llobregat DWTP (coded as PTLL), the finished water of the Ter DWTP (coded as PTT), and reverse osmosis-desalinated water (coded as ITAM) per $s e$ or in mixtures. The investigated mixtures included: a mixture of equal volumes of the two DWTP final products (M1), and mixtures of each DWTP finished water with ITAM (80:20, v/v) (M2 with PTLL and M3 with PTT). All of them were 
representative scenarios occurring at different locations along the drinking water distribution network. Note that blending the final products of the three different treatment plants, i.e., PTLL, PTT and ITAM, within the distribution network is an operational strategy commonly adopted to deliver water of high quality in this system. DBP formation potential (DBPFP) tests were carried out in headspace-free $500 \mathrm{~mL}$ amber glass bottles without adding extra chlorine, i.e., using the residual free chlorine present in the different matrices $(0.85 \mathrm{mg} / \mathrm{L}$ in PTLL, $0.98 \mathrm{mg} / \mathrm{L}$ in PTT, $0.68 \mathrm{mg} / \mathrm{L}$ in ITAM, $0.62 \mathrm{mg} / \mathrm{L}$ in $\mathrm{M} 1,0.54 \mathrm{mg} / \mathrm{L}$ in $\mathrm{M} 2$ and $0.78 \mathrm{mg} / \mathrm{L}$ in $\mathrm{M} 3$ ), in order to perform the study with residual free chlorine concentrations that can be commonly found at the outlet of the different plants and in the distribution network. These bottles were incubated either at $15{ }^{\circ} \mathrm{C}$ or $30{ }^{\circ} \mathrm{C}$ to evaluate DBP formation at the average source water temperature and at the worst case scenario (source water temperature above the maximum registered in the area), respectively. These bottles were analyzed at different contact times $(0,24,48$ and $72 \mathrm{~h})$ to simulate different residence times along the large distribution system $(1000 \mathrm{Km}$ of pipelines of different diameters $(10-300$ $\mathrm{cm})$ ). All glassware used was pretreated overnight with a concentrated solution of chlorine (about $100 \mathrm{ppm}$ ) and thoroughly rinsed with deionized water.

\subsection{Physical-chemical characterization of water matrices}

Finished waters and mixtures were physical-chemically characterized at $\mathrm{t}=0$. Validated standard operating procedures were used in all cases.

Total organic carbon (TOC) measurements were carried out by means of Shimadzu TOC-VCSH analyzer (Shimadzu Europa GmbH, Duisburg, Germany). Water $\mathrm{pH}$ and conductivity were measured using a benchtop pHmeter and electrical conductivity meter (Multimeter MM41, Crison).

Ion chromatography(IC)-conductivity with a Methrom 882 Compact IC plusAnion equipped with an IC Professional Conductivity Detector (Methrom AG) was used to measure chloride and bromide. A 858 Professional Autosampler (Methrom) was used for sample injection $(20 \mu \mathrm{L})$. Ion separation was achieved with a Metrosep A Supp $5-250(205$ x $4 \mathrm{~mm})$ preceded by a Metrosep A Supp 1 guard column (5 x $4.6 \mathrm{~mm})$, using $\mathrm{Na} 2 \mathrm{CO} 3(3.2 \mathrm{mmol} / \mathrm{L})$ and $\mathrm{NaHCO} 3(1 \mathrm{mmol} / \mathrm{L})$ as eluent (flow rate 
of $0.7 \mathrm{~mL} / \mathrm{min}$ ). For data acquisition and handling, the MagIC Net22 software was used.

Analysis of iodide was carried out with an ion chromatograph Dionex IC5000 coupled to a suppressed conductivity detector (Thermo Fisher Scientific). For analysis, $25 \mu \mathrm{L}$ of the water sample was injected by means of a Dionex AS-AP autosampler. Ion chromatography was achieved using a IonPac ${ }^{\circledR}$ AS18 anionexchange column $(4 \times 250 \mathrm{~mm})$ preceded by an AG Guard column $(4 \times 50 \mathrm{~mm})$ and $\mathrm{KOH}$ eluent generator $(12-15 \mathrm{mM} \mathrm{KOH})$ using an eluent flow rate of $1 \mathrm{~mL} / \mathrm{min}$. Determination of iodide was carried out at a wavelength of $230 \mathrm{~nm}$. Data acquisition and evaluation were carried out with Chromeleon 6.8 software.

Specific ultraviolet absorbance (SUVA) of the different water matrices was calculated after measuring UV absorbance of the water at $254 \mathrm{~nm}$ with a spectrophotometer.

Residual free chlorine was measured in all DBPFP test samples by means of a Pocket Colorimeter II (Hach) using the DPD (N, N-diethyl-p-phenylenediamine) colorimetric method.

\subsection{Analysis of DBPs}

All DBP analyses were carried out in duplicate. The list of target compounds and further details on the chemicals is provided in Table 1.

For quality assurance, blanks consisting of LC-grade water containing the internal standard (1,2-dibromopropane) and the quenching agent were also processed with the analytical protocols, to discard any artifact that could result in false positives. 
Table 1 - Target DBPs, and corresponding acronyms, CAS numbers, purity and provider of the analytical standard, molecular formula and monoisotopic mass.

\begin{tabular}{|c|c|c|c|c|c|c|}
\hline $\begin{array}{l}\text { DBP } \\
\text { class }\end{array}$ & Analyte & Acronym & CAS \# & $\begin{array}{l}\text { Provider } \\
\text { (purity, \%) }\end{array}$ & $\begin{array}{l}\text { Molecular } \\
\text { formula }\end{array}$ & $\begin{array}{c}\text { Mono- } \\
\text { isotopic } \\
\text { Mass (Da) }\end{array}$ \\
\hline \multirow{4}{*}{$\begin{array}{l}\text { Regulated } \\
\text { trihalo- } \\
\text { methanes } \\
\text { (THM4) }\end{array}$} & Chloroform & TCM & $67-66-3$ & Sigma (>99) & $\mathrm{Cl}_{3} \mathrm{CH}$ & 117.91 \\
\hline & Bromodichloromethane & BDCM & $75-27-4$ & Sigma $(>99)$ & $\mathrm{BrCl}_{2} \mathrm{CH}$ & 161.86 \\
\hline & Dibromochloromethane & DBCM & $124-48-1$ & Sigma $(>99)$ & $\mathrm{Br}_{2} \mathrm{ClCH}$ & 205.81 \\
\hline & Bromoform & TBM & $75-25-2$ & Sigma (>99) & $\mathrm{Br}_{3} \mathrm{CH}$ & 249.76 \\
\hline \multirow{6}{*}{$\begin{array}{l}\text { lodinated } \\
\text { trihalo- } \\
\text { methanes (I } \\
\text { THMs) }\end{array}$} & Dichloro-iodomethane & $\mathrm{DCIM}$ & $594-04-7$ & CanSyn (>95) & $\mathrm{Cl}_{2} \mathrm{ICH}$ & 209.85 \\
\hline & Chloro-bromo-iodomethane & BCIM & $34970-00-8$ & CanSyn (>95) & $\mathrm{BrClICH}$ & 253.80 \\
\hline & Dibromo-iodomethane & DBIM & $593-94-2$ & CanSyn (90-95) & $\mathrm{Br}_{2} \mathrm{ICH}$ & 297.75 \\
\hline & - Chloro-diiodomethane & CDIM & $638-73-3$ & CanSyn (90-95) & $\mathrm{Cl}_{2} \mathrm{CH}$ & 301.79 \\
\hline & Bromo-diiodomethane & BDIM & $557-95-9$ & CanSyn (90-95) & $\mathrm{Brl}_{2} \mathrm{CH}$ & 345.73 \\
\hline & Triiodomethane (lodoform) & TIM & $75-47-8$ & Sigma (99) & $\mathrm{I}_{3} \mathrm{CH}$ & 393.72 \\
\hline \multirow{4}{*}{$\begin{array}{l}\text { Trihalo- } \\
\text { acetal- } \\
\text { dehydes } \\
\text { (THALs) }\end{array}$} & Trichloroacetaldehyde(chloral) & TCAL & $75-87-6$ & Sigma $(>98)$ & $\mathrm{Cl}_{3} \mathrm{C}-\mathrm{CHO}$ & 145.91 \\
\hline & Bromodichloroacetaldehyde & BDCAL & $34619-29-9$ & CanSyn (90-95) & $\mathrm{BrCl}_{2} \mathrm{C}-\mathrm{CHO}$ & 189.86 \\
\hline & Dibromochloroacetaldehyde & DBCAL & $64316-11-6$ & CanSyn (90-95) & $\mathrm{Br}_{2} \mathrm{ClC}-\mathrm{CHO}$ & 233.81 \\
\hline & Tribromoacetaldehyde & TBAL & $115-17-3$ & Sigma (>97) & $\mathrm{Br}_{3} \mathrm{C}-\mathrm{CHO}$ & 277.76 \\
\hline \multirow{9}{*}{$\begin{array}{l}\text { Halo-aceto- } \\
\text { nitriles } \\
\text { (HANs) }\end{array}$} & Chloroacetonitrile & CAN & $107-14-2$ & Sigma (>99) & $\mathrm{ClCH}_{2}-\mathrm{CN}$ & 74.99 \\
\hline & Bromoacetonitrile & BAN & $590-17-0$ & Sigma (>97) & $\mathrm{BrCH}_{2}-\mathrm{CN}$ & 118.94 \\
\hline & lodoacetonitrile & IAN & $624-75-9$ & Sigma (>98) & $\mathrm{ICH}_{2}-\mathrm{CN}$ & 166.92 \\
\hline & Dichloroacetonitrile & DCAN & $3018-12-0$ & Sigma $(>98)$ & $\mathrm{CHCl}_{2}-\mathrm{CN}$ & 108.95 \\
\hline & Dibromoacetonitrile & DBAN & $3252-43-5$ & Sigma (>90) & $\mathrm{CHBr}_{2}-\mathrm{CN}$ & 196.85 \\
\hline & Trichloroacetonitrile & TCAN & $545-06-2$ & Sigma $(>98)$ & $\mathrm{CCl}_{3}-\mathrm{CN}$ & 142.91 \\
\hline & Bromodichloroacetonitrile & BDCAN & $60523-73-1$ & CanSyn (>85) & $\mathrm{CBrCl}_{2}-\mathrm{CN}$ & 186.86 \\
\hline & Dibromochloroacetonitrile & DBCAN & $144772-39-4$ & CanSyn (>85) & $\mathrm{CBr}_{2} \mathrm{Cl}-\mathrm{CN}$ & 230.81 \\
\hline & Tribromoacetonitrile & TBAN & $75519-19-6$ & CanSyn (90-95) & $\mathrm{CBr}_{3}-\mathrm{CN}$ & 274.76 \\
\hline \multirow{11}{*}{$\begin{array}{l}\text { Halo- } \\
\text { acetamides } \\
\text { (HACMs) }\end{array}$} & 2-Chloroacetamide & CACM & $79-07-2$ & Sigma $(>98)$ & $\mathrm{ClCH}_{2}-\mathrm{CONH}_{2}$ & 92.99 \\
\hline & Bromochloroacetamide & BCACM & $62872-24-8$ & CanSyn (>99) & $\mathrm{BrClCH}-\mathrm{CONH}{ }_{2}$ & 170.91 \\
\hline & Dichloroacetamide & DCACM & $683-72-7$ & Simga (>99) & $\mathrm{Cl}_{2} \mathrm{CH}-\mathrm{CONH}{ }_{2}$ & 126.96 \\
\hline & Dibromoacetamide & DBACM & $598-70-9$ & CanSyn (>99) & $\mathrm{Br}_{2} \mathrm{CH}-\mathrm{CONH}{ }_{2}$ & 214.86 \\
\hline & Chloroiodoacetamide & CIACM & $62872-35-9$ & CanSyn (>99) & $\mathrm{ClICH}-\mathrm{CONH}{ }_{2}$ & 218.89 \\
\hline & Bromoiodoacetamide & BIACM & $62872-36-0$ & CanSyn $(>85)$ & $\mathrm{BrlCH}-\mathrm{CONH}{ }_{2}$ & 262.84 \\
\hline & Diiodoacetamide & DIACM & $5875-23-0$ & CanSyn (>99) & $\mathrm{I}_{2} \mathrm{CH}-\mathrm{CONH}_{2}$ & 310.83 \\
\hline & Trichloroacetamide & TCACM & $594-65-0$ & Sigma $(>99)$ & $\mathrm{Cl}_{3} \mathrm{C}-\mathrm{CONH} \mathrm{N}_{2}$ & 160.92 \\
\hline & Bromodichloroacetamide & BDCACM & $98137-00-9$ & CanSyn (>99) & $\mathrm{BrCl}_{2} \mathrm{C}-\mathrm{CONH}{ }_{2}$ & 204.87 \\
\hline & Dibromochloroacetamide & DBCACM & $855878-13-6$ & CanSyn (>99) & $\mathrm{ClBr}_{2} \mathrm{C}-\mathrm{CONH} \mathrm{N}_{2}$ & 248.82 \\
\hline & Tribromoacetamide & TBACM & $594-47-8$ & CanSyn (>99) & $\mathrm{Br}_{3} \mathrm{C}-\mathrm{CONH} \mathrm{H}_{2}$ & 292.77 \\
\hline \multirow{12}{*}{$\begin{array}{l}\text { Halo-acetic } \\
\text { acids } \\
\text { (HAAs) }\end{array}$} & Chloroacetic acid & CAA & $79-11-8$ & Sigma $(>99)$ & $\mathrm{ClCH}_{2}-\mathrm{COOH}$ & 93.98 \\
\hline & Bromoacetic acid & BAA & $79-08-3$ & Sigma $(>99)$ & $\mathrm{BrCH}_{2}-\mathrm{COOH}$ & 137.93 \\
\hline & lodo acetic acid & IAA & $64-69-7$ & Sigma (98) & $\mathrm{ICH}_{2}-\mathrm{COOH}$ & 185.92 \\
\hline & Chlorobromo acetic acid & BCAA & $5589-96-8$ & Sigma (>99) & $\mathrm{BrClCH}-\mathrm{COOH}$ & 171.89 \\
\hline & Dichloroacetic acid & DCAA & $79-53-6$ & Sigma $(>99)$ & $\mathrm{Cl}_{2} \mathrm{CH}-\mathrm{COOH}$ & 127.94 \\
\hline & Dibromoacetic acid & DBAA & $631-64-1$ & Sigma $(>99)$ & $\mathrm{Br}_{2} \mathrm{CH}-\mathrm{COOH}$ & 215.84 \\
\hline & Chloroiodoacetic acid & CIAA & $53715-09-6$ & CanSyn $(>90)$ & $\mathrm{CllCH}-\mathrm{COOH}$ & 219.88 \\
\hline & Bromoiodoacetic acid & BIAA & $71815-43-5$ & CanSyn (>85) & $\mathrm{BrICH}-\mathrm{COOH}$ & 263.83 \\
\hline & Diiodoacetic acid & DIAA & $598-89-00$ & CanSyn $(>90)$ & $\mathrm{I}_{2} \mathrm{CH}-\mathrm{COOH}$ & 311.81 \\
\hline & Trichloroacetic acid & TCAA & $76-03-9$ & Sigma $(>99)$ & $\mathrm{Cl}_{3} \mathrm{C}-\mathrm{COOH}$ & 161.90 \\
\hline & Bromodichloroacetic acid & BDCAA & $71133-14-7$ & Sigma $(>99)$ & $\mathrm{BrCl}_{2} \mathrm{C}-\mathrm{COOH}$ & 205.85 \\
\hline & Dibromochloroacetic acid & DBCAA & $5278-95-5$ & Sigma $(>99)$ & $\mathrm{Br}_{2} \mathrm{ClC}-\mathrm{COOH}$ & 249.80 \\
\hline
\end{tabular}




\section{Analysis of regulated trihalomethanes}

Analysis of THM4 was performed by means of headspace-gas chromatographymass spectrometry (HS-GC-MS) using a TriPlus 300 headspace autosampler and a Trace 1300 GC-ECD system (Thermo Scientific).

After free chlorine quench with sodium thiosulfate $0.1 \mathrm{~N}(0.1 \%$ in water, v/v $), 10$ $\mathrm{mL}$ of the water sample was transferred to a $20-\mathrm{mL}$ headspace vial, capped with Teflon-faced septa caps. The vial was incubated at $60{ }^{\circ} \mathrm{C}$ for $15 \mathrm{~min}$ for sample equilibration. Additional operating conditions were $140{ }^{\circ} \mathrm{C}$ at the valve/sample loop, $140{ }^{\circ} \mathrm{C}$ at the transfer line, and 1 bar as pressurization and carrier gas pressures, respectively, $12 \mathrm{~s}$ of pressurization time, $12 \mathrm{~s}$ of venting time and $30 \mathrm{~s}$ of transfer time.

Chromatographic separation of THM4 (see Figure 2) was achieved using a TraceGold TG-624 column (30 m, $0.25 \mathrm{~mm}$ x $1.4 \mathrm{~mm}$, Thermo Scientific) and helium as carrier gas. $\mathrm{GC}$ oven temperature increased from $60{ }^{\circ} \mathrm{C}$ to $200{ }^{\circ} \mathrm{C}$ at a rate of $10^{\circ} \mathrm{C} / \mathrm{min}$. Data acquisition and processing were performed using Chromeleon 7.

Quantitation was performed by means of internal standard calibration with a curve constructed between the concentration range of $0.5-50 \mu \mathrm{g} / \mathrm{L}$. THM4 were identified according to their GC retention time, as compared as a THM4 standard solution (see Table 2).

\begin{tabular}{cccc}
\hline & $\begin{array}{c}\text { Retention } \\
\text { time [min] }\end{array}$ & $\mathbf{R}^{\mathbf{2}}$ & $\begin{array}{c}\text { Linearity range } \\
{[\boldsymbol{\mu g} / \mathrm{L}]}\end{array}$ \\
\hline Chloroform & 4.945 & 0.9925 & $0.5-50$ \\
Bromodichloromethane & 6.511 & 0.9909 & $0.5-50$ \\
Dibromochloromethane & 8.026 & 0.9913 & $0.5-50$ \\
Bromoform & 9.434 & 0.9941 & $0.5-50$ \\
\hline
\end{tabular}

Table 2 - Retention time and linearity obtained after GC-ECD analysis of trihalomethanes. 


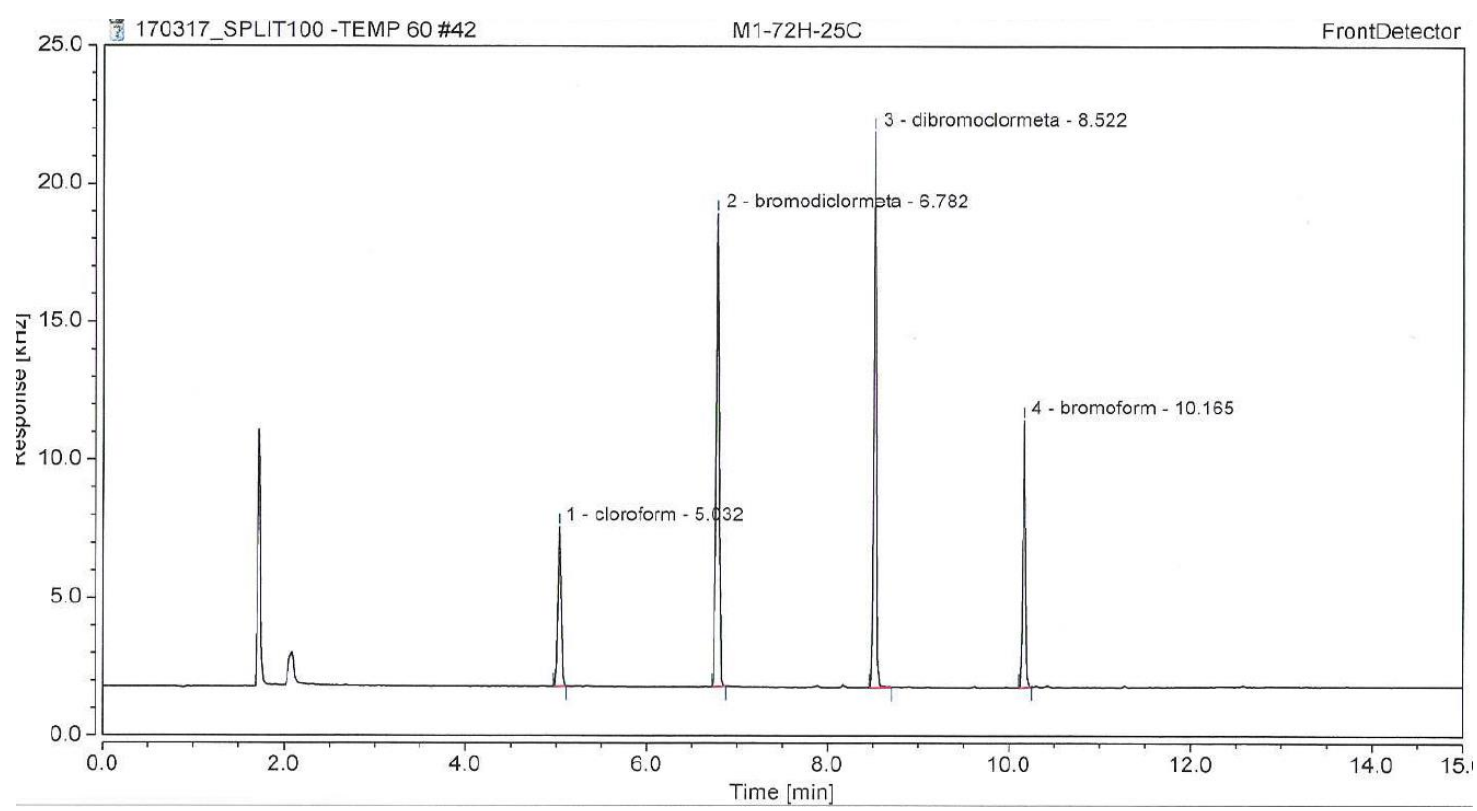

Figure 2. GC-ECD chromatogram of trihalomethanes in a water sample.

\subsubsection{Analysis of emerging DBPs}

The extraction approach used for the analysis of emerging DBPs in the DBP mixtures was based on the US Environmental Protection Agency (USEPA) method for the analysis of DBPs in drinking water (Hodgeson and Cohen 1990).

Ascorbic acid (2.5 mg/L, ACS reagent grade, Sigma Aldrich) freshly prepared in Milli-Q-grade water was used to quench residual free chlorine in the samples and preserve the target DBPs. All samples were extracted in duplicate. For extraction, 100 $\mathrm{mL}$ of water was acidified to $\mathrm{pH}<0.5$ with $5 \mathrm{~mL}$ of concentrated sulphuric acid $\left(\mathrm{H}_{2} \mathrm{SO}_{4}, 95-97 \%\right.$, ACS reagent grade, Sigma Aldrich) and then $30 \mathrm{~g}$ of dried granular sodium sulphate $\left(\mathrm{Na}_{2} \mathrm{SO}_{4}\right.$, ACS reagent grade, Sigma Aldrich) was added to increase the ionic strength of the water and favour the partition of the analytes into the organic solvent. After dissolution, the internal standard (IS) $(100 \mu \mathrm{L} \times 0.8 \mu \mathrm{g} / \mathrm{mL}$ of $1,2-$ dibromopropane (Sigma Aldrich) in methyl tert-butyl ether (MTBE; >99.8\%, Sigma Aldrich) was added and mixed in the solution. Finally, the extracting solvent $(2.5 \mathrm{~mL}$ of MTBE) was added. Samples were agitated with a mechanical shaker (SF1, Stuart) at $500 \mathrm{rpm}$ for $30 \mathrm{~min}$. After settling for $5 \mathrm{~min}$, the top layer (MTBE) was removed and passed through a $\mathrm{Na}_{2} \mathrm{SO}_{4}$ column to remove water molecules. The MTBE extract was split into two vials. One vial was directly injected into the gas chromatographyelectron ionization-mass spectrometry (GC-EI-MS) instrument for analysis of target I- 
THMs, HANs, HACMs, and THALs. The content of the other vial $(0.4 \mathrm{~mL})$ was derivatized with $0.2 \mathrm{~mL}$ of freshly prepared diazomethane to form the methyl esters of HAAs that are more volatile than HAAs and thus, amenable to GC-MS analysis. Diazomethane was produced using diazald by means of a diazomethane generator (Sigma Aldrich), following the manufacturer indications.

Quantification, based on peak areas, was performed by the internal standard method. Calibration curves were constructed using least squares linear regression analysis with a minimum of five calibration data points. Calibration solutions were obtained by spiking the target analytes within the range $0.1-75 \mu \mathrm{g} / \mathrm{L}$ to LC-grade water aliquots and processing them as if they were samples.

Data acquisition was carried out with Chemstation software (Agilent), whereas data processing was carried out with Xcalibur 3.1.66.7 (Thermo Fisher)

\subsubsection{GC-EI/MS analysis of I-THMs, HANs, HACMs, and THALs.}

Analytical determination of I-THMs, THALs, HANs and HACMS in MTBE extracts was performed using a 6890 Series GC connected in series to a 5973 Network MSD (Agilent Technologies). One $\mu \mathrm{L}$ of the MTBE extract was injected by means of and automated injector 7638B Series in splitless mode (split flow=50 mL/min, splitless time $=1.5 \mathrm{~min}$ ) onto a capillary GC column Rtx-200 MS (30 m x $0.25 \mathrm{~mm}$ x $0.25 \mu \mathrm{m})($ Restek, Teknokroma, Barcelona). The temperatures of the injector, the GCMS transfer line and the MS source were set to $200{ }^{\circ} \mathrm{C}, 280{ }^{\circ} \mathrm{C}$ and $200{ }^{\circ} \mathrm{C}$, respectively. Chromatographic separation was achieved using a constant flow rate of Helium $(1.2 \mathrm{~mL} / \mathrm{min})$ and the following temperature gradient: $30^{\circ} \mathrm{C}$ maintained for 5 minutes, then increased at $9{ }^{\circ} \mathrm{C} / \mathrm{min}$ to $165^{\circ} \mathrm{C}$, and at $20^{\circ} \mathrm{C} / \mathrm{min}$ to $285^{\circ} \mathrm{C}$ (held for 10 minutes).

The analyzer was operated in selected ion monitoring (SIM) mode. A minimum of four ions was registered per analyte (see Table 3). Figure 3 shows the total ion chromatogram obtained after analysis of a standard solution at a concentration of $200 \mu \mathrm{g} / \mathrm{mL}$ (equivalent to $5 \mu \mathrm{g} / \mathrm{L}$ ) in water. 


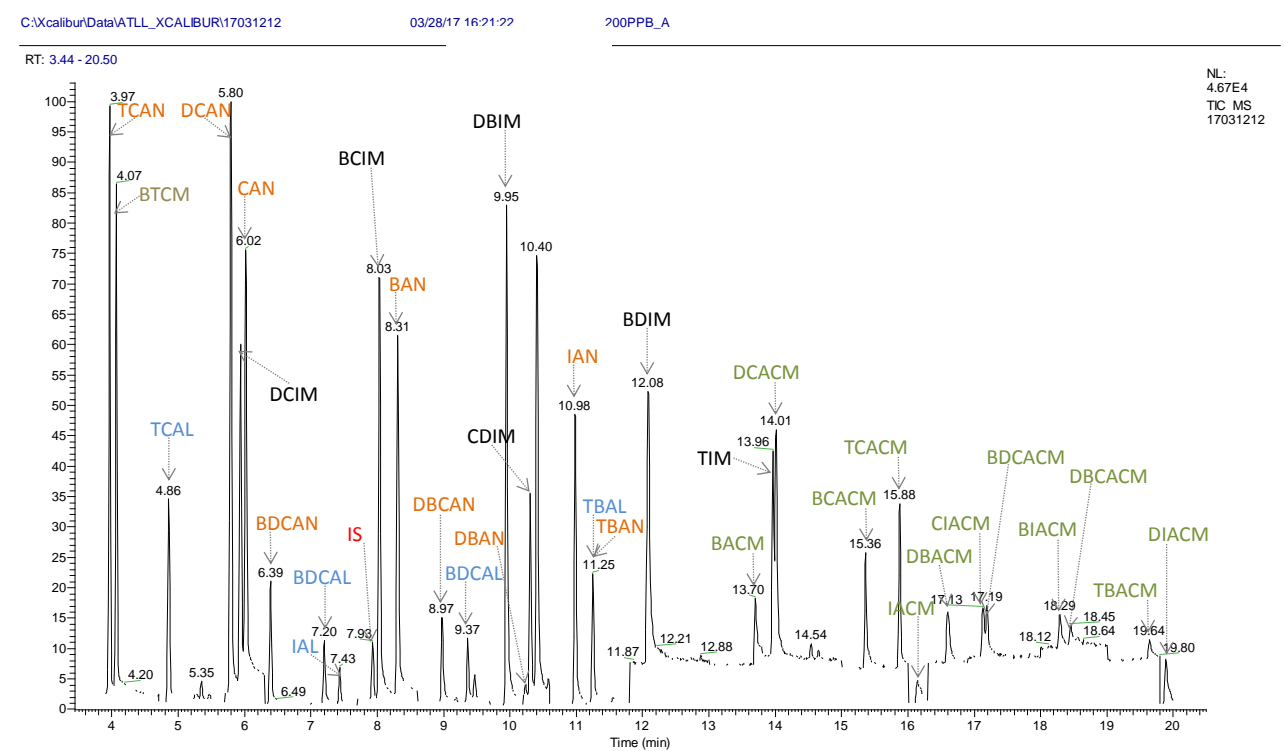

Figure 3. Total ion chromatogram (TIC) obtained after GC-EI/MS analysis of a 200 $\mu \mathrm{g} / \mathrm{mL}$ MTBE solution containing the target analytes (I-THMs are indicated in black color, THALs in blue color, HANs in orange color, and HACMs in green color).

\subsubsection{GC-NCI/MS analysis of HAAs.}

Analytical determination of methyl esters of HAAs was performed using a 7890A GC connected in series to a 5975C Inert XL MSD (Agilent Technologies). Ionization was carried out in the negative chemical ionization mode using methane. One $\mu \mathrm{L}$ of the extract was injected by means of an automated injector 7638B Series in splitless mode (split flow $=50 \mathrm{~mL} / \mathrm{min}$, splitless time $=1.5 \mathrm{~min}$ ) onto a capillary GC column Sapiens X5ms (30 m x $0.25 \mathrm{~mm} \times 0.25 \mu \mathrm{m})$ (Teknokroma, Barcelona). The temperatures of the injector, the GC/MS transfer line and the MS source were set to $200{ }^{\circ} \mathrm{C}, 280{ }^{\circ} \mathrm{C}$ and $200{ }^{\circ} \mathrm{C}$, respectively. Chromatographic separation was achieved using a constant flow rate of Helium $(1.2 \mathrm{~mL} / \mathrm{min})$ and the following temperature gradient: $35{ }^{\circ} \mathrm{C}$ maintained for 5 minutes, then increased at $5{ }^{\circ} \mathrm{C} / \mathrm{min}$ to $110{ }^{\circ} \mathrm{C}$, and at $20^{\circ} \mathrm{C} / \mathrm{min}$ to $285^{\circ} \mathrm{C}$ (held for 10 minutes).

The analyzer was operated in SIM mode. A minimum of two ions was registered per analyte (see Table 3). Figure 4 shows the total ion chromatogram obtained after analysis of a standard solution at a concentration of $200 \mu \mathrm{g} / \mathrm{mL}$ (equivalent to $5 \mu \mathrm{g} / \mathrm{L}$ ) in water. 


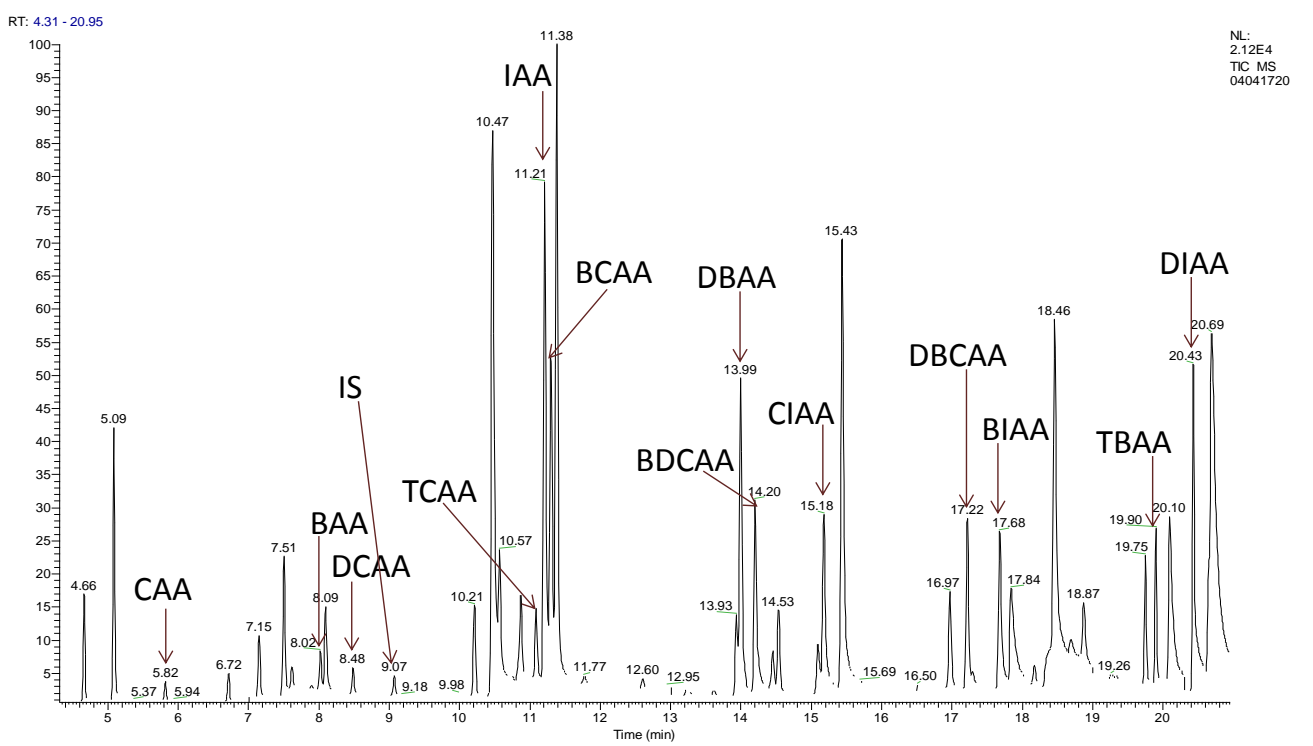

Figure 4. Total ion chromatogram (TIC) obtained after GC-NCI/MS analysis of a 200 $\mu \mathrm{g} / \mathrm{mL}$ MTBE solution containing the methyl esters of the target HAAs.

\subsubsection{Method performance}

Method performance was evaluated in terms of linearity, sensitivity, precision (intra-day repeatability) and accuracy (analyte recovery), and it is summarized in Table 3. Method sensitivity was estimated from the analyte signal observed at the lowest calibration solutions. Limits of detection and limits of quantification (or method reporting limits, MRL) corresponded with the analyte concentration that provided a signal-to-noise ratio of 3 and 10, respectively. I-THMs, THALs, and HANs could be detected at concentrations below $1 \mu \mathrm{g} / \mathrm{L}$. On the contrary, the sensitivity of the analytical method for HACMs and HAAs was lower.

Analyte recovery and method repeatability were evaluated through a recovery study. For this, LC-grade waters were fortified with the target DBPs at two different levels ( $\mathrm{n}=4$ at $1 \mu \mathrm{g} / \mathrm{L}$ and $\mathrm{n}=4$ at $5 \mu \mathrm{g} / \mathrm{L}$ ) and extracted following the analytical protocols described. The ratio between the analyte peak area and the IS peak area obtained in fortified samples was compared with the ratio of obtained in standard solutions at equivalent concentrations $(40 \mu \mathrm{g} / \mathrm{L}$ and $200 \mu \mathrm{g} / \mathrm{L})$. The worst analyte recoveries were obtained for HACMs and HAAs, which is directly related to the low method sensitivity observed for these compounds. Analyte losses were automatically corrected in the quantification process because calibration solutions were prepared by 
fortifying LC-grade water at different concentrations and processing these solutions as if they were samples. 
Table 3 - Retention time and ions monitored for GC-MS analysis of the target DBPs. Quantification ion is highlighted in bold.

\begin{tabular}{|c|c|c|c|c|c|c|}
\hline \multirow[b]{2}{*}{ Class } & \multirow[b]{2}{*}{ Analyte } & \multirow[b]{2}{*}{$\operatorname{SIM}(\mathrm{m} / \mathrm{z})$} & \multirow[b]{2}{*}{$t_{R}{ }^{*}$} & \multicolumn{2}{|c|}{ Linearity } & \multirow{2}{*}{$\begin{array}{c}\text { Method } \\
\text { reporting } \\
\text { limit }(\mu \mathrm{g} / \mathrm{L})\end{array}$} \\
\hline & & & & $\operatorname{Range}(\mu \mathrm{g} / \mathrm{L})$ & $\mathbf{R}^{2}$ & \\
\hline \multirow{6}{*}{ I-THMs } & DCIM & $83,127,175,210$ & $5.86 \pm 0.18$ & $0.1-25$ & 0.9980 & 0.10 \\
\hline & $\mathrm{BCIM}$ & $127,129,175,254,256$ & $7.96 \pm 0.09$ & $0.25-50$ & 0.9991 & 0.25 \\
\hline & DBIM & $173,171,127,300$ & $9.87 \pm 0.10$ & $0.1-75$ & 0.9984 & 0.10 \\
\hline & CDIM & $175,177,127,302$ & $10.33 \pm 0.09$ & $0.1-10$ & 0.9979 & 0.10 \\
\hline & BDIM & $\mathbf{2 1 9}, 127,140,346$ & $12.01 \pm 0.06$ & $0.25-10$ & 0.9982 & 0.25 \\
\hline & TIM & $267,394,127,140$ & $13.88 \pm 0.05$ & $0.1-10$ & 0.9920 & 0.10 \\
\hline \multirow{4}{*}{ THALs } & $\overline{T C A L}$ & $82,84,111,117$ & $4.78 \pm 0.36$ & $0.25-50$ & 0.9952 & 0.25 \\
\hline & BDCAL & $83,111,128,164$ & $7.13 \pm 0.15$ & $0.5-25$ & 0.9953 & 0.50 \\
\hline & DBCAL & $127,129,157,208$ & $9.29 \pm 0.09$ & $0.5-25$ & 0.9971 & 0.5 \\
\hline & TBAL & $173,175,252$ & $11.17 \pm 0.07$ & $0.25-25$ & 0.9949 & 0.25 \\
\hline \multirow{9}{*}{ HANs } & CAN & $75,77,48,50$ & $5.95 \pm 0.19$ & $0.25-75$ & 0.9975 & 0.25 \\
\hline & BAN & $119,121,79$ & $8.25 \pm 0.09$ & $0.25-25$ & 0.9984 & 0.25 \\
\hline & IAN & $167,127,139$ & $10.92 \pm 0.05$ & $0.1-10$ & 0.9962 & 0.1 \\
\hline & DCAN & $74,76,82,84$ & $5.72 \pm 0.17$ & $0.1-75$ & 0.9978 & 0.1 \\
\hline & DBAN & $118, \mathbf{1 2 0}, 199,79$ & $10.24 \pm 0.06$ & $0.25-25$ & 0.9924 & 0.25 \\
\hline & TCAN & $108,110,47$ & $3.91 \pm 0.52$ & $0.1-75$ & 0.9971 & 0.1 \\
\hline & BDCAN & $108,110,154,152$ & $6.32 \pm 0.19$ & $1-50$ & 0.9946 & 1 \\
\hline & DBCAN & $154,152,79,198$ & $8.90 \pm 0.11$ & $1-50$ & 0.9970 & 1 \\
\hline & TBAN & $198,200,117$ & $11.17 \pm 0.07$ & $0.5-10$ & 0.9923 & 0.5 \\
\hline \multirow{11}{*}{ HACMs } & CACM & $44,49,93,95$ & $12.0 \pm 0.06$ & $2.5-75$ & 0.9962 & 2.5 \\
\hline & BCACM & $44,173,93,129$ & $15.3 \pm 0.03$ & $5-75$ & 0.9942 & 5 \\
\hline & DCACM & $44,85,83,127,129$ & $13.96 \pm 0.1$ & $5-75$ & 0.9947 & 5 \\
\hline & DBACM & $44,215,122,174$ & $16.53 \pm 0.03$ & $5-75$ & 0.9951 & 5 \\
\hline & CIACM & $44,219,176,127$ & $17.04 \pm 0.07$ & $5-75$ & 0.9911 & 5 \\
\hline & BIACM & $138,220,263,127,44$ & $18.20 \pm 0.03$ & $5-75$ & 0.9919 & 5 \\
\hline & DIACM & $127, \mathbf{1 8 4}, 311,156$ & $19.83 \pm 0.03$ & $5-75$ & 0.9921 & 5 \\
\hline & TCACM & $44,82,98,126$ & $15.81 \pm 0.03$ & $1-25$ & 0.9944 & 1 \\
\hline & BDCACM & $44,126,82$ & $17.12 \pm 0.02$ & $2.5-75$ & 0.9927 & 2.5 \\
\hline & DBCACM & $44,128,93$ & $18.37 \pm 0.03$ & $5-75$ & 0.9958 & 5.0 \\
\hline & TBACM & $44,81, \mathbf{1 7 2 , 1 0 5}$ & $19.56 \pm 0.02$ & $2.5-25$ & 0.9921 & 2.5 \\
\hline \multirow{12}{*}{ HAAs } & CAA & 35,37 & $5.77 \pm 0.52$ & $1-25$ & 0.9910 & 1 \\
\hline & BAA & 79,81 & $8.02 \pm 0.09$ & $0.5-10$ & 0.9971 & 0.5 \\
\hline & IAA & 127,199 & $11.20 \pm 0.08$ & $2.5-75$ & 0.9971 & 2.5 \\
\hline & BCAA & 79,81 & $11.29 \pm 0.04$ & $5-75$ & 0.9952 & 5 \\
\hline & DCAA & 35,37 & $8.47 \pm 0.12$ & $5-75$ & 0.9981 & 5 \\
\hline & DBAA & 79,81 & $13.99 \pm 0.00$ & $5-75$ & 0.9949 & 5 \\
\hline & CIAA & $127,35,37$ & $15.17 \pm 0.02$ & $5-75$ & 0.9952 & 5 \\
\hline & BIAA & $127,79,81$ & $17.68 \pm 0.02$ & $5-75$ & 0.9983 & 5 \\
\hline & DIAA & $127,167,184$ & $20.43 \pm 0.00$ & $2.5-75$ & 0.9969 & 2.5 \\
\hline & TCAA & 35,37 & $11.07 \pm 0.09$ & $1-50$ & 0.9971 & 1 \\
\hline & BDCAA & $35,37,79,81$ & $14.20 \pm 0.10$ & $5-75$ & 0.9915 & 5 \\
\hline & DBCAA & $79,81,35,37$ & $17.21 \pm 0.00$ & $10-75$ & 0.9910 & 10 \\
\hline
\end{tabular}

*average \pm standard deviation 


\subsection{Toxicity risk assessment}

Toxicity of the DBP mixtures was evaluated using an additive model. The toxic equivalent concentrations (TEQ) of each DBP mixture was calculated using the concentration of each DBP in the mixture $\left(\mathrm{C}_{\mathrm{i}}\right)$ and the corresponding toxic equivalency factor $\left(\mathrm{TEF}_{\mathrm{i}}\right)\left(T E Q=\sum\left[C_{i}\right] \times T E F_{i}\right)$ [12]. TEFs for each DBP, shown in Table 4, were calculated using iodoacetic acid, one of the most toxic DBPs known to date, as the reference compound and the equation $T E F_{i}=E C_{r e f} / E C_{i}$, where $\mathrm{EC}_{\text {ref }}$ is the effective toxic concentration of iodoacetic acid and $\mathrm{EC}_{\mathrm{i}}$ is the effective toxic concentration of a selected DBP.

The cytotoxic and genotoxic potencies of DBPs to mammalian Chinese hamster ovary cells were considered for toxicity assessment because both toxic effects have been systematically investigated for 103 DBPs in identical in vitro assays and such database, available in the literature, allows for DBP toxicity comparison [9]. The cytotoxic EC corresponded to the DBP concentration that induced a cell density that was $50 \%$ of that observed in the negative control $\left(\mathrm{LC}_{50}\right)$, whereas the genotoxic EC was the DBP concentration that induced migration of $50 \%$ of the cell DNA outside of the nucleus (midpoint of the DNA tail moment, 50\% TDNA). 
Table 4 - Effective cytotoxic $\left(\mathrm{LC}_{50}\right)$ and genotoxic (50\% TDNA) concentrations and toxic equivalency factors (relative to iodoacetic acid) of the investigated DBPs $\left(\mathrm{TEF}_{\mathrm{CY}}\right.$ and $\mathrm{TEF}_{\mathrm{GEN}}$ ).

\begin{tabular}{|c|c|c|c|c|c|}
\hline Class & DBP & $\mathrm{LC}_{50}(\mathrm{M})$ & TEF $_{\text {СYTO }}$ & $50 \%$ TDNA (M) & $\mathrm{TEF}_{\mathrm{GEN}}$ \\
\hline \multirow{4}{*}{ THM4 } & TCM & $9.62 \mathrm{E}-03$ & 3.07E-04 & NA & \\
\hline & BDCM & 1.15E-02 & $2.57 \mathrm{E}-04$ & NA & \\
\hline & DBCM & $5.36 \mathrm{E}-03$ & $5.50 \mathrm{E}-04$ & NA & \\
\hline & TBM & $3.96 \mathrm{E}-03$ & 7.45E-04 & NA & \\
\hline \multirow{6}{*}{ I-THMs } & DCIM & $4.13 \mathrm{E}-03$ & 7.14E-04 & NA & \\
\hline & $\mathrm{BCIM}$ & $2.42 \mathrm{E}-03$ & $1.22 \mathrm{E}-03$ & NA & \\
\hline & DBIM & 1.91E-03 & 1.54E-03 & NA & \\
\hline & CDIM & 2.40E-03 & 1.23E-03 & 2.95E-03 & $2.95 \mathrm{E}-03$ \\
\hline & BDIM & $1.40 \mathrm{E}-03$ & $2.11 \mathrm{E}-03$ & NA & \\
\hline & TIM & $6.60 \mathrm{E}-05$ & 4.47E-02 & NA & \\
\hline \multirow{4}{*}{ THALs } & TCAL & $1.16 \mathrm{E}-03$ & $2.54 \mathrm{E}-03$ & NA & \\
\hline & BDCAL & 2.04E-05 & 1.45E-01 & 4.70E-04 & 1.85E-02 \\
\hline & DBCAL & $5.15 \mathrm{E}-06$ & $5.73 \mathrm{E}-01$ & 1.44E-04 & 6.04E-02 \\
\hline & TBAL & $3.58 E-06$ & 8.24E-01 & 3.40E-04 & 2.56E-02 \\
\hline \multirow{9}{*}{ HANs } & CAN & $6.83 \mathrm{E}-05$ & 4.32E-02 & $6.01 \mathrm{E}-04$ & $1.45 \mathrm{E}-02$ \\
\hline & BAN & $3.21 \mathrm{E}-06$ & $9.19 \mathrm{E}-01$ & $3.85 \mathrm{E}-05$ & $2.26 \mathrm{E}-01$ \\
\hline & IAN & 3.30E-06 & 8.94E-01 & 3.71E-05 & 2.35E-01 \\
\hline & DCAN & $5.73 \mathrm{E}-05$ & 5.15E-02 & 2.75E-03 & $3.16 \mathrm{E}-03$ \\
\hline & DBAN & $2.85 \mathrm{E}-06$ & $1.04 \mathrm{E}+00$ & 4.71E-05 & 1.85E-01 \\
\hline & TCAN & $1.60 \mathrm{E}-04$ & $1.84 \mathrm{E}-02$ & $1.01 E-03$ & 8.61E-03 \\
\hline & BDCAN & NR & & NR & \\
\hline & DBCAN & NR & & NR & \\
\hline & TBAN & NR & & NR & \\
\hline \multirow{11}{*}{ HACMs } & CACM & $1.48 \mathrm{E}-04$ & 1.99E-02 & $1.38 \mathrm{E}-03$ & $6.30 \mathrm{E}-03$ \\
\hline & BCACM & $1.71 \mathrm{E}-05$ & $1.73 \mathrm{E}-01$ & $5.83 \mathrm{E}-04$ & 1.49E-02 \\
\hline & DCACM & 1.92E-03 & 1.54E-03 & NA & \\
\hline & DBACM & $1.22 \mathrm{E}-05$ & 2.42E-01 & 7.44E-04 & 1.17E-02 \\
\hline & CIACM & $5.97 \mathrm{E}-06$ & $4.94 \mathrm{E}-01$ & $3.02 E-04$ & $2.88 \mathrm{E}-02$ \\
\hline & BIACM & 3.81E-06 & 7.74E-01 & 7.21E-05 & 1.21E-01 \\
\hline & DIACM & $3.78 \mathrm{E}-07$ & $7.80 \mathrm{E}+00$ & 3.39E-05 & $2.57 \mathrm{E}-01$ \\
\hline & TCACM & 2.05E-03 & $1.44 \mathrm{E}-03$ & $6.54 \mathrm{E}-03$ & 1.33E-03 \\
\hline & BDCACM & $8.68 \mathrm{E}-06$ & 3.40E-01 & 1.46E-04 & 5.96E-02 \\
\hline & DBCACM & 4.75E-06 & $6.21 \mathrm{E}-01$ & $6.94 \mathrm{E}-05$ & 1.25E-01 \\
\hline & TBACM & $3.14 \mathrm{E}-06$ & 9.39E-01 & 3.25E-05 & $2.68 \mathrm{E}-01$ \\
\hline \multirow{12}{*}{ HAAs } & CAA & $8.10 \mathrm{E}-04$ & $3.64 \mathrm{E}-03$ & $4.11 \mathrm{E}-04$ & $2.12 \mathrm{E}-02$ \\
\hline & BAA & $9.60 \mathrm{E}-06$ & 3.07E-01 & 1.70E-05 & $5.12 \mathrm{E}-01$ \\
\hline & IAA & 2.95E-06 & $1.00 \mathrm{E}+00$ & 8.70E-06 & $1.00 \mathrm{E}+00$ \\
\hline & BCAA & 7.78E-04 & 3.79E-03 & 3.64E-03 & 2.39E-03 \\
\hline & DCAA & 7.30E-03 & 4.04E-04 & N.A. & \\
\hline & DBAA & $5.90 \mathrm{E}-04$ & $5.00 \mathrm{E}-03$ & 1.76E-03 & 4.94E-03 \\
\hline & CIAA & 3.04E-04 & 9.70E-03 & NA & \\
\hline & BIAA & 8.97E-04 & $3.29 \mathrm{E}-03$ & $3.16 \mathrm{E}-03$ & 2.75E-03 \\
\hline & DIAA & $3.30 \mathrm{E}-04$ & 8.94E-03 & $1.98 \mathrm{E}-03$ & 4.39E-03 \\
\hline & TCAA & 2.40E-03 & 1.23E-03 & NA & \\
\hline & BDCAA & 6.85E-04 & 4.31E-03 & NA & \\
\hline & DBCAA & 2.02E-04 & 1.46E-02 & 1.36E-02 & $6.40 \mathrm{E}-04$ \\
\hline
\end{tabular}

${ }^{*} \mathrm{NA}$ : not available, NR: not investigated 


\section{Results and discussion}

\subsection{DBP formation potential of disinfected drinking water matrices}

The concentration of residual free chlorine during the DBPFP tests is shown in Figures 5 and 6.

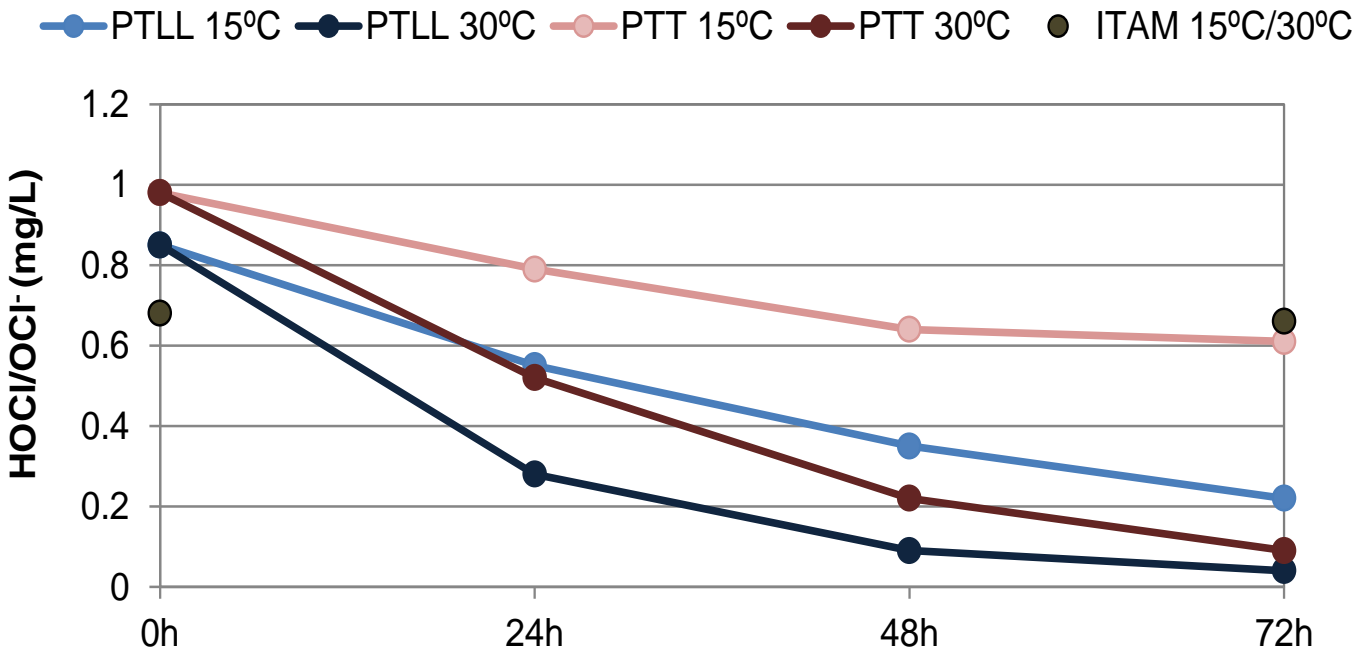

Figure 5. Concentration of residual free chlorine (in $\mathrm{mg} / \mathrm{L}$ ) in DWTP finished water matrices and desalinated water at different temperatures and residence times.

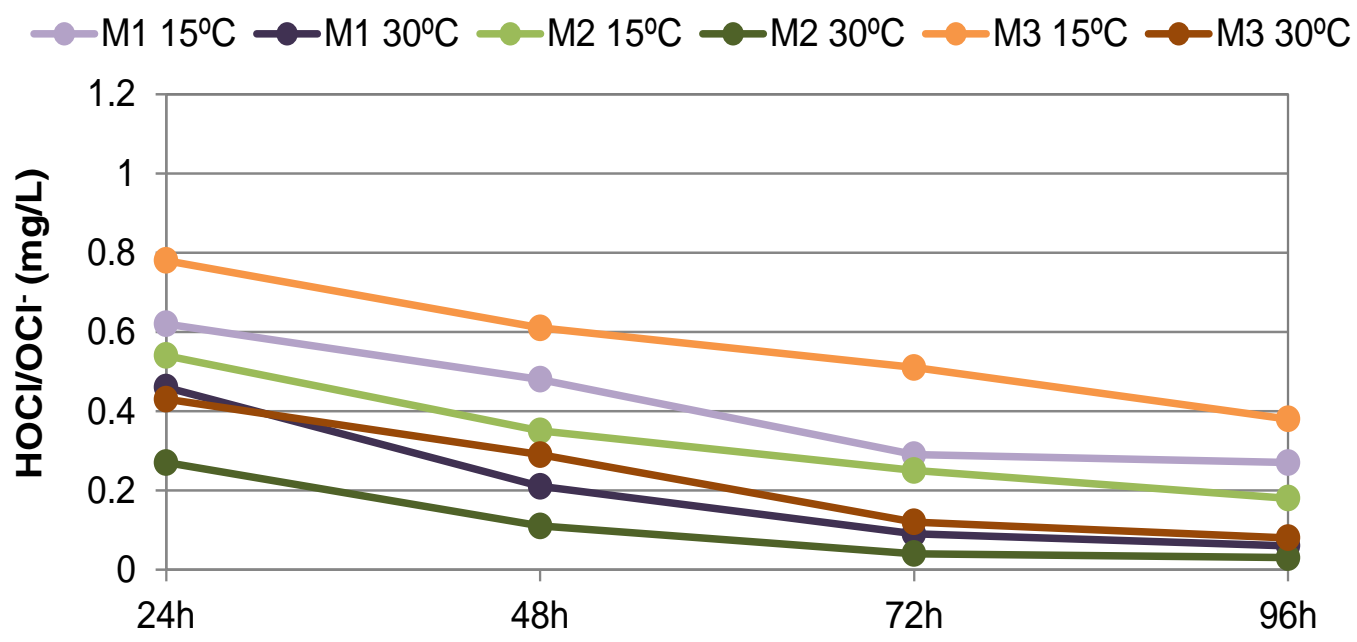

Figure 6. Concentration of residual free chlorine (in $\mathrm{mg} / \mathrm{L}$ ) in the mixtures at different temperatures and residence times. 
Figures 7 and 8 show the DBP concentrations found in the finished water of the Llobregat DWTP (PTLL) and the Ter DWTP (PTT) and in the different mixtures at $\mathrm{t}=0$. Since finished waters were collected at the outlet of each treatment facility storage tank, DBP mixtures at $\mathrm{t}=0$ reflected the formation potential of disinfected plant effluents after the tank hydraulic residence time (about $20 \mathrm{~h}$ for PTLL, $25 \mathrm{~h}$ for PPT and $8 \mathrm{~h}$ for ITAM). In the case of the mixtures, performed after $24 \mathrm{~h}$ of finished water collection to ensure the desired water temperature, DBP concentrations at $t=0$ were the result of the hydraulic residence time and $24 \mathrm{~h}$ of incubation time. Concentrations of DBPs below the method reporting limit (MRL) (see Table 3) were substituted by half of the corresponding MRL for graphic representation and calculations. Main physical-chemical properties of the investigated water matrices are shown in Table 5.

Table 5. Physical-chemical characterization of the water matrices investigated.

\begin{tabular}{ccccccccc}
\hline $\begin{array}{c}\text { Water } \\
\text { matrix }\end{array}$ & $\begin{array}{c}\mathbf{T}^{*} \\
\left({ }^{\mathbf{0}} \mathbf{C}\right)\end{array}$ & $\mathbf{p H}$ & $\begin{array}{c}\text { TOC } \\
(\mathbf{m g} / \mathbf{L})\end{array}$ & $\begin{array}{c}\text { SUVA } \\
\mathbf{L} / \mathbf{m g}-\mathbf{M}\end{array}$ & $\begin{array}{c}\mathbf{C o n d} . \\
(\boldsymbol{\mu S} / \mathbf{c m})\end{array}$ & $\begin{array}{c}\mathbf{C l}^{-} \\
(\mathbf{m g} / \mathbf{L})\end{array}$ & $\begin{array}{c}\mathbf{B r}^{-} \\
(\boldsymbol{\mu g} / \mathbf{L})\end{array}$ & $\begin{array}{c}\mathbf{I}^{-} \\
(\boldsymbol{\mu g} / \mathbf{L})\end{array}$ \\
\hline PTLL & 15 & 7.61 & 1.86 & 1.52 & 982 & 1140 & 218 & $<25$ \\
\hline PTT & 12 & 7.68 & 1.84 & 1.69 & 374 & 12.2 & 0.0 & $<25$ \\
\hline ITAM & 14 & 8.09 & 0.0 & 0.006 & 527 & 79.7 & 356 & $<25$ \\
\hline M1 & - & 8.17 & 1.90 & 1.47 & 754 & 62.8 & 74 & $<25$ \\
M2 & - & 8.18 & 1.52 & 1.70 & 881 & 108.5 & 223 & $<25$ \\
\hline M3 & - & 8.07 & 1.40 & 1.65 & 461 & 24.7 & 80 & $<25$ \\
\hline \multicolumn{7}{c}{ *Temperature of the water collected at the storage tank outlets } & &
\end{tabular}

Despite the low conductivity of the Ter River water $(374 \mu \mathrm{S} / \mathrm{cm})$ as compared to the Llobregat River water $(982 \mu \mathrm{S} / \mathrm{cm}$ ) (see Table 5), its DBPFP $(\Sigma \mathrm{DBP}=120 \mu \mathrm{g} / \mathrm{L})$ is only slightly below that of the Llobregat River water $(\Sigma \mathrm{DBP}=134 \mu \mathrm{g} / \mathrm{L})$, which could be attributed to their similar TOC content. Mixing both DWTP finished waters in equal proportions (after $24 \mathrm{~h}$ of collection) resulted in a mixture (M1) with TOC content comparable to that of its component matrices and intermediate conductivity (754 $\mu \mathrm{S} / \mathrm{cm}$ ), but DBPFP slightly lower (up to 9\%) than PTLL and higher (up to $18 \%$ ) than PTT $\left(\Sigma \mathrm{DBP}=138 \mu \mathrm{g} / \mathrm{L}\right.$ at $15^{\circ} \mathrm{C}$ and $168 \mu \mathrm{g} / \mathrm{L}$ at $30^{\circ} \mathrm{C}$ ). The blending of DWTP finished waters with ITAM (TOC $=0$ and $\Sigma \mathrm{DBP}=0.5$ $\mu \mathrm{g} / \mathrm{L}$ ) contributed to reducing their original DBPFP (between 22-26\%, after comparing $2 \mathrm{DBP}$ in $\mathrm{M} 2$ and M3 at $\mathrm{t}=0$ with PTT and PTLL at $\mathrm{t}=24$ at both investigated temperatures) due to dilution of their OM content $(\Sigma \mathrm{DBP}=109 \mu \mathrm{g} / \mathrm{L}$ in 
diluted PTLL (M2) and $\Sigma \mathrm{DBP}=99 \mu \mathrm{g} / \mathrm{L}$ in diluted PTT (M3) at $15^{\circ} \mathrm{C}$ ). However, OM properties of DWTP finished water matrices, dominated by slightly hydrophilic, low aromaticity and low molecular weight fractions [13], were not affected by dilution with ITAM, and thus, similar DBP potential could be expected. However, water matrices with similar SUVA value (and dissolved organic carbon content) may behave differently in the presence of the same disinfection agent [14].

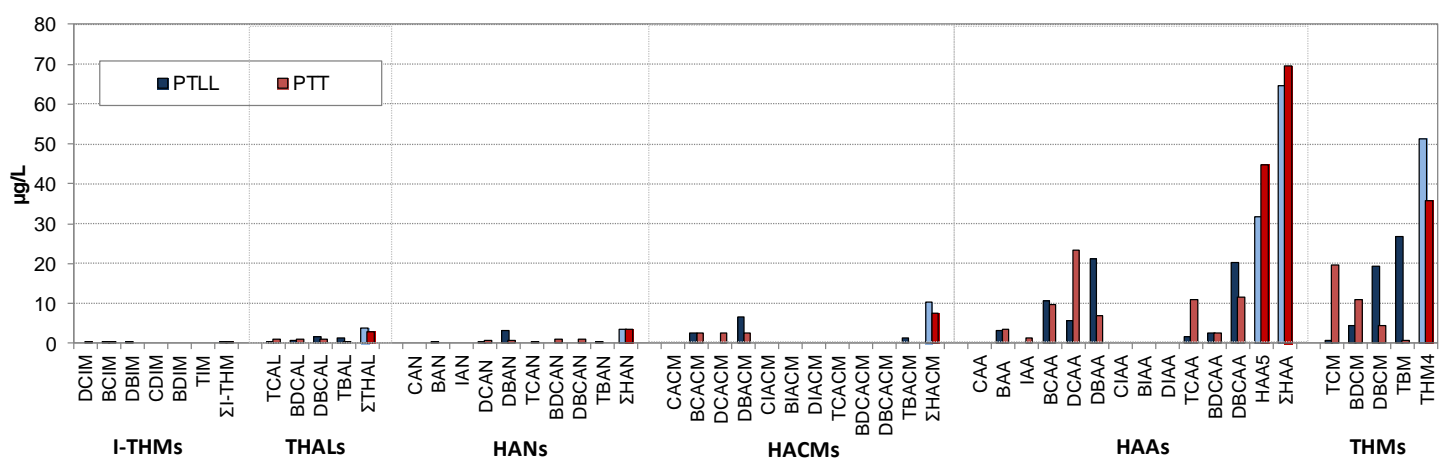

Figure 7. DBP formation potential of the DWTP finished water matrices (PTLL and PTT) at $\mathrm{t}=0$.
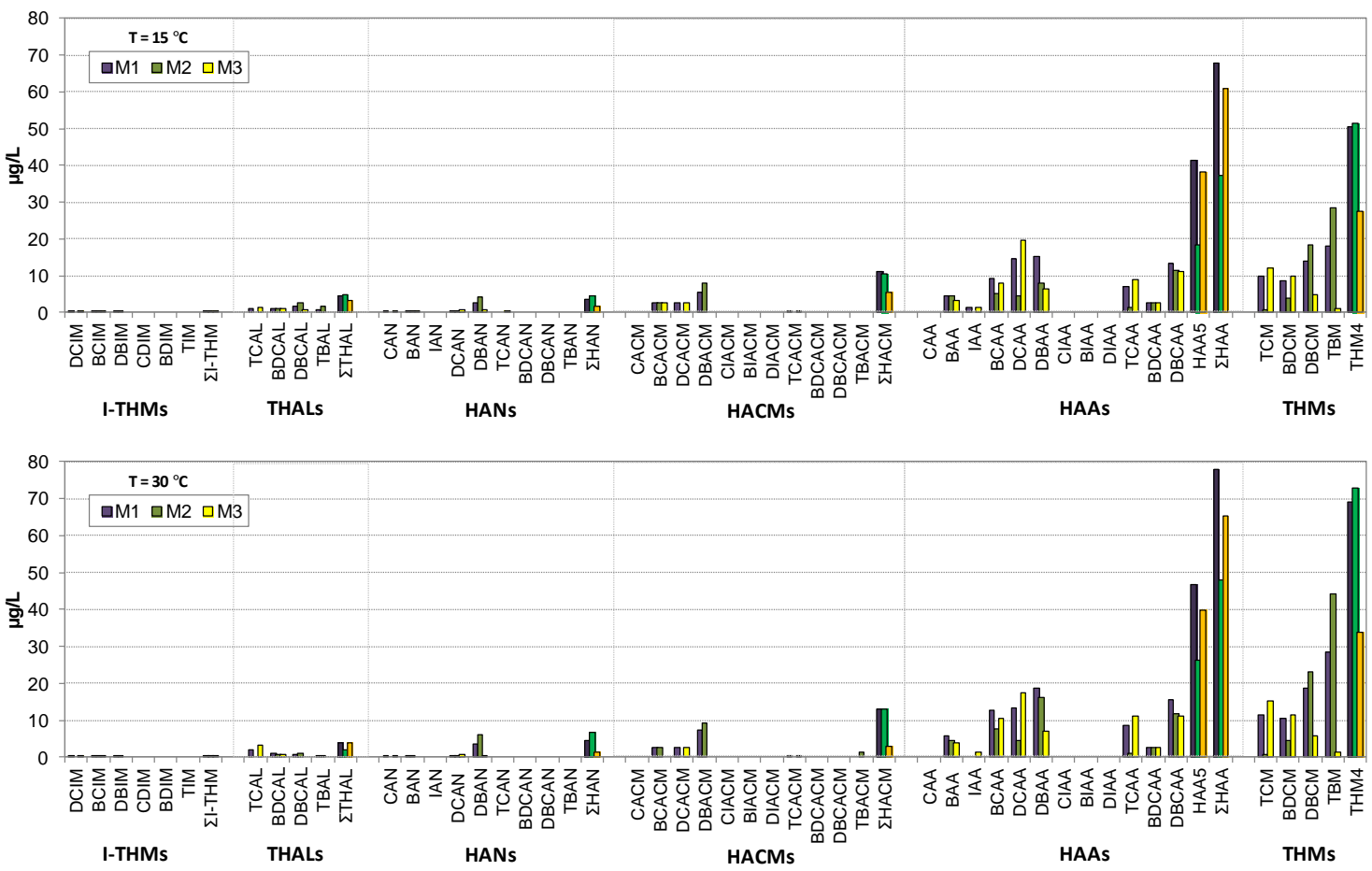

Figure 8. DBP formation potential of the mixtures (M1, M2, and M3) at $t=0$ at both temperatures investigated $\left(15^{\circ} \mathrm{C}\right.$ and $\left.30^{\circ} \mathrm{C}\right)(\mathrm{M} 1$ : PTT+PTLL $(1: 1, \quad v / v) ; \mathrm{M} 2$ : PTLL+ITAM (8:2, v/v), M3: PTT+ITAM (8:2, v/v)). 
$\mathrm{Br}^{-}$content, and therefore water conductivity, had a direct effect on DBPFP. High $\mathrm{Br}^{-}$content waters, such as PTLL $\left(218 \mu \mathrm{g} / \mathrm{L}\right.$ of $\left.\mathrm{Br}^{-}\right)$and its mixtures M1 (74 $\mu \mathrm{g} / \mathrm{L}$ of $\left.\mathrm{Br}^{-}\right)$and M2 $\left(223 \mu \mathrm{g} / \mathrm{L}\right.$ of $\left.\mathrm{Br}^{-}\right)$presented, as expected, high formation potential of Br-DBPs (see Figures 1 and 2 and Table 1). Note that the Llobregat DWTP was upgraded (i.e., incorporation of EDR treatment) to reduce bromide of the incoming source water to a level that resulted in low DBP formation and still allowed the operational and economic feasibility of the treatment process (e.g., $40 \%$ of source water threated with EDR during the sampling date). Besides the use of advanced treatments, the blending of different waters is another management strategy applied to minimize the presence of DBPs in drinking water. In the investigated supply network, the formation potential of Br-DBPs of PTLL was reduced up to $40 \%$ after mixture with PTT $\left(\mathrm{Br}^{-}=0\right)$, due to dilution of Br-DBP concentrations in PTLL ( $\left.24 \mathrm{~h}\right)$. The blending of ITAM with DWTP finished water matrices incorporated $\mathrm{Br}^{-}$ions into the mixtures, more specifically, into M3. However, the incorporation of additional $\mathrm{Br}^{-}$to the mixture did not have an immediate relevant effect on the formation of Br-DBPs (at $\mathrm{t}=0$ ), being the effect of NOM dilution much more evident. Blending had indeed a reduction effect in the Br-DBP formation potential of PTLL, whereas it enhanced that of PTT at long residence times.

Formation of THMs and other DBP classes (trihalogenated HAAs, HANs, and halonitromethanes) was reported to decrease at increasing $\mathrm{pH}$ values [15-17]. Although the $\mathrm{pH}$ value was slightly higher in all mixtures (8-8.2) as compared to PTLL and PTT (7.6), other aspects seemed to be more decisive than water $\mathrm{pH}$ in the DBPFP of the investigated water matrices. Such $\mathrm{pH}$ difference could be attributed to the reactions that took place in the source waters (PTLL and PTT) during the 24-h that were incubated before preparing the mixtures so that the desired water temperature was reached.

Elevated water temperatures $\left(30^{\circ} \mathrm{C}\right)$ contributed to increase the DBPFP of the water. The highest impact of temperature in the overall DBPFP was observed in the mixtures containing PTLL $(31 \%$ in $\mathrm{M} 2, \Sigma \mathrm{DBP}=143 \mu \mathrm{g} / \mathrm{L}$, and $23 \%$ in $\mathrm{M} 1$, $\Sigma \mathrm{DBP}=169 \mu \mathrm{g} / \mathrm{L})$. On the contrary, DBPFP of M3 was increased only in $9 \%$ $(\Sigma \mathrm{DBP}=108 \mu \mathrm{g} / \mathrm{L})$. 
Overall, DBP concentrations in the investigated supply system were similar to those measured in different drinking water networks that rely on chlorine as disinfectant all over the world [18-34] (see Tables 6-11).

Table 6 - Range and average (x) concentration (in $\mu \mathrm{g} / \mathrm{L}$ ) of THM4 in the investigated DBP mixtures and values reported in the literature for this DBP class in other drinking water supply systems.

\begin{tabular}{|c|c|c|c|c|c|c|c|c|c|c|}
\hline & \multicolumn{2}{|c|}{ TCM } & \multicolumn{2}{|c|}{ BDCM } & \multicolumn{2}{|c|}{ DBCM } & \multicolumn{2}{|c|}{ TBM } & \multicolumn{2}{|c|}{ THM4 } \\
\hline & Range & $x$ & Range & $x$ & Range & $X$ & Range & $x$ & Range & $x$ \\
\hline PTLL & $0.8-1.1$ & 1.0 & $4.4-8.0$ & 6.7 & $19-34$ & 28.5 & $27-71$ & 50 & $51-114$ & 86 \\
\hline$\overline{\mathrm{PTT}}$ & $19-41$ & 28 & $11-22$ & 16 & $4.5-9.8$ & 7.5 & $0.8-1.4$ & 1.2 & $36-74$ & 53 \\
\hline ITAM & & n.d. & & n.d. & & n.d. & $0.5-2.5$ & 1.3 & $0.5-2.5$ & 1.3 \\
\hline M1 & $9.8-12$ & 11 & $8.7-13$ & 12 & $14-27$ & 22 & $18.4-42$ & 31 & $51-94$ & 76 \\
\hline $\mathrm{M} 2$ & $0.7-0.8$ & 0.7 & $4.0-4.9$ & 4.6 & $18-25$ & 23 & $28-64$ & 49 & $52-95$ & 77 \\
\hline$\overline{\mathrm{M} 3}$ & $12-19$ & 16 & $9.8-17$ & 13 & $4.8-20$ & 13 & $1.0-26$ & 12 & $28-83$ & 55 \\
\hline US [32] & $22-34$ & & $4.3-34$ & & $0.7-13$ & & n.d. -2 & & $31-83$ & \\
\hline $\begin{array}{l}\text { Istambul, } \\
\text { Turquía [30] }\end{array}$ & $0.7-51$ & $32 *$ & n.d. -49 & $24 *$ & n.d.-55 & $15 *$ & n.d. -30 & $2.0^{*}$ & $0.7-151$ & $76^{*}$ \\
\hline $\begin{array}{l}\text { Pereira, } \\
\text { Colombia [31] }\end{array}$ & & 50 & & 2.3 & & 1.6 & & 1.4 & & 56 \\
\hline $\begin{array}{l}\text { Barcelona, } \\
\text { Spain [19] } \\
\end{array}$ & & 9.5 & & 21 & & 34 & & 26 & & 91 \\
\hline $\begin{array}{l}\text { Limassol, } \\
\text { Cyprus [24] }\end{array}$ & $1.3-13$ & 9.0 & $2.7-17$ & 10 & 3.4-17 & 7.3 & $3.7-19.9$ & 11.0 & $21-57$ & 38 \\
\hline $\begin{array}{l}\text { Nicosia, Cypru } \\
{[24]}\end{array}$ & $3.3-31$ & 15 & $2.3-29$ & 15 & $0.07-23$ & 10.7 & $0.06-4.9$ & 2.9 & $8.7-86$ & 43 \\
\hline China [20] & $0.2-38$ & 8.8 & $0.1-31$ & 4.9 & n.d. -28 & 4.5 & n.d. -74 & 4.5 & $0.8-107$ & 19 \\
\hline $\begin{array}{ll}\text { Saudi } & \text { Arabic } \\
\text { [34] } & \end{array}$ & & & & & & & & & $0.1-52$ & $10 / 19$ \\
\hline $\begin{array}{l}\text { Newfoundland } \\
\text { \&Labrador, } \\
\text { Canada [33] }\end{array}$ & & & & & & & & & $\begin{array}{l}0-772 / \\
0-1200\end{array}$ & $32 / 98$ \\
\hline
\end{tabular}

n/a: compound not analyzed; n.d.: compound not detected; x: average value, *: median value.

[32] - Finished water from one DWTP using chlorine (Plant \#4, $n=5$ ).

[30] - Tap water from a chlorine-based DWTP distribution system $(n=40)$.

[31] - Finished water from a chlorine-based DWTP $(n=30)$.

[19] - Tap water from a chlorine-based DWTP distribution system $(n=40)(n=21)$.

[24] - Tap water from a chlorine-based DWTP distribution system $(\mathrm{n}=18)$.

[24] - Tap water from a chlorine-based DWTP distribution system $(n=20)$.

[20] - Finished water from 70 DWTPs (7 DWTPs used chloramines, 3 DWTPs used $\mathrm{ClO}_{2}$ and chlorine was used in the remaining ones).

[34] - Chlorinated desalinated water/blended water (mixture of desalinated and treated groundwater, 40-60\%) from a distribution system in Saudi Arabia $(\mathrm{n}=38)$

[33] - 441 chlorine-based drinking water systems for 18 years in Newfoundland and Labrador

(Canada) 4 samples per year, $\mathrm{n}=19700$. Groundwater sourced/Surface water sourced 
Table 7 - Range and average (x) concentration (in $\mu \mathrm{g} / \mathrm{L}$ ) of the HAAs detected in the investigated DBP mixtures and values reported in the literature for these DBPs in other drinking water supply systems.

\begin{tabular}{|c|c|c|c|c|c|c|c|c|}
\hline & \multicolumn{2}{|c|}{ CAA } & \multicolumn{2}{|c|}{ BAA } & \multicolumn{2}{|c|}{ IAA } & \multicolumn{2}{|c|}{ DCAA } \\
\hline & Range & $x$ & Range & $x$ & Range & $x$ & Range & $x$ \\
\hline PTLL & & n.d. & $3.2-6.2$ & 5.2 & & $<2.5$ & $5.1-6.0$ & 5.7 \\
\hline PTT & & $<0.5$ & $3.6-5.2$ & 4.5 & & $<2.5$ & $22-29$ & 26 \\
\hline ITAM & & n.d. & & n.d. & & n.d. & & \\
\hline M1 & & n.d. & $2.9-5.9$ & 5.1 & & $<2.5$ & $7.5-16$ & 12 \\
\hline M2 & & n.d. & $2.2-4.6$ & 3.8 & & n.d. & $4.2-5.4$ & 4.8 \\
\hline M3 & & $<0.5$ & $3.0-5.4$ & 4.3 & & $<2.5$ & $11-22$ & 17 \\
\hline Canada [22] & $0-7.6$ & & & $<\mathrm{LOQ}$ & & $\mathrm{n} / \mathrm{a}$ & $0-113$ & \\
\hline $\begin{array}{l}\text { Istambul, } \\
\text { Turkey [30] } \\
\end{array}$ & $1.4-9.7$ & 4.05 & $<0.03-14$ & 8.2 & & $\mathrm{n} / \mathrm{a}$ & $0.9-4.1$ & 2.4 \\
\hline China [20] & & n.d. & & n.d. & & $\mathrm{n} / \mathrm{a}$ & n.d.- 53 & 6.3 \\
\hline Greece [21] & $1.5-53$ & & $0.1-0.7$ & & & $\mathrm{n} / \mathrm{a}$ & $2.9-25$ & \\
\hline US [32] & n.d. -8.2 & & n.d.-1 & & & & $17-27$ & \\
\hline US [28] & & & & & $0.002-0.7$ & & & \\
\hline
\end{tabular}

n/a: compound not analyzed, n.d.: not detected; x: average value; *: median value.

[22] - Finished water and from the distribution network of 25 chlorine-based DWTP (HAA5) (BAA and DBAA <LOQ).

[30] - Tap water from a chlorine-based DWTP distribution system $(\mathrm{n}=40)$ (TBAA - 0.11-6.46 ppb).

[20] - Finished water from 70 DWTPs (7 DWTPs used chloramines, 3 DWTPs used $\mathrm{ClO}_{2}$ and chlorine was used in the remaining ones) - (TBAA was not detected).

[21] - Finished water from 4 chlorine-based DWTPs.

[32] - Finished water from one DWTP using chlorine (Plant \#4, n=5) (TBAA was not detected).

[28] - Finished water from 23 DWTPs (21 DWTPs used chloramines and 2 DWTPs using chlorine as final disinfectant) - Only IAA, BIAA, DIAA were analyzed (BIAA (0.005-0.29 ppb), DIAA (0.003$0.09 \mathrm{ppb})$ ). 
Table 7 (cont.) - Range and average (x) concentration (in $\mu \mathrm{g} / \mathrm{L}$ ) of the HAAs detected in the investigated DBP mixtures and values reported in the literature for these DBPs in other drinking water supply systems.

\begin{tabular}{|c|c|c|c|c|c|c|c|c|c|c|}
\hline & DBA & & BCA & & TC & & BDCA & & DBCA & \\
\hline & Range & $x$ & Range & & Range & $x$ & Range & $x$ & Range & $x$ \\
\hline PTLL & $21-37$ & 28 & $11-13$ & 11.4 & $1.5-1.7$ & 1.6 & & $<5$ & $11-20$ & 15 \\
\hline PTT & $6.2-7.6$ & 7.6 & $8.0-18$ & 13.2 & $11-17$ & 14 & $<5-8.8$ & 5.9 & $11-14$ & 12 \\
\hline ITAM & n.d. & n.d. & & & & $<1$ & & n.d. & & n.d. \\
\hline M1 & $14-24$ & 18 & $8.6-13$ & 10.9 & $5.2-8.8$ & 6.7 & $<5-5.2$ & 2.8 & $12-17$ & 14 \\
\hline M2 & $8.0-33$ & 20 & $5.1-11$ & 8.1 & $1.1-1.5$ & 1.3 & & $<2.5$ & $11-18$ & 13 \\
\hline M3 & $6.4-13$ & 9.5 & $8.0-12$ & 10.0 & $7.2-11$ & 9.9 & $<5-6.6$ & 3.4 & $11-13$ & 12 \\
\hline $\begin{array}{l}\text { Canada } \\
{[22]}\end{array}$ & & $<\mathrm{LOQ}$ & & & $3.2-190$ & & & $\mathrm{n} / \mathrm{a}$ & & $\mathrm{n} / \mathrm{a}$ \\
\hline $\begin{array}{l}\text { Istambul, } \\
\text { Turkey } \\
{[30]}\end{array}$ & $<0.01-23$ & 8.9 & $<0.02-8.5$ & 5.00 & $2.3-22$ & 12 & $<0.03-6 . c$ & 1.5 & $<0.05-0.6$ & 0.1 \\
\hline China [20] & n.d.- 5.8 & 2.8 & n.d.- 4.4 & 2.54 & n.d.-16 & 5.6 & n.d.- 4.8 & 3.3 & n.d- 4.8 & 4.5 \\
\hline $\begin{array}{l}\text { Greece } \\
{[21]}\end{array}$ & & & $0.5-6.6$ & & $5.1-18$ & & & $\mathrm{n} / \mathrm{a}$ & & $\mathrm{n} / \mathrm{a}$ \\
\hline US [32] & n.d. -2.8 & & $1.7-8$ & & $20-35$ & & $3.3-13$ & & n.d. -3.8 & \\
\hline
\end{tabular}

n/a: compound not analyzed; n.d.: not detected; x: average value, *: median value.

[22] - Finished water and from the distribution network of 25 chlorine-based DWTP (HAA5) (BAA and DBAA <LOQ).

[30] - Tap water from a chlorine-based DWTP distribution system (n=40) (TBAA - 0.11-6.46 ppb).

[20] - Finished water from 70 DWTPs (7 DWTPs used chloramines, 3 DWTPs used $\mathrm{ClO}_{2}$ and chlorine was used in the remaining ones) - (TBAA was not detected).

[21] - Finished water from 4 chlorine-based DWTPs.

[32] - Finished water from one DWTP using chlorine (Plant \#4, n=5) (TBAA was not detected).

[28] - Finished water from 23 DWTPs (21 DWTPs used chloramines and 2 DWTPs using chlorine as final disinfectant) - Only IAA, BIAA, DIAA were analyzed (BIAA (0.005-0.29 ppb), DIAA (0.003$0.09 \mathrm{ppb}))$. 
Table 8 - Range and average (x) concentration (in $\mu \mathrm{g} / \mathrm{L}$ ) of the HACMs detected in the investigated DBP mixtures and values reported in the literature for these DBPs in other drinking water supply systems.

\begin{tabular}{|c|c|c|c|c|c|c|c|c|c|c|}
\hline & \multicolumn{2}{|c|}{ DBACM } & \multicolumn{2}{|c|}{ DCACM } & \multicolumn{2}{|c|}{ BCACM } & \multicolumn{2}{|c|}{ TCACM } & \multicolumn{2}{|c|}{ TBACM } \\
\hline & Range & $x$ & Range & $x$ & Range & $x$ & Range & $x$ & Range & $x$ \\
\hline PTLL & $6.6-10$ & 8.0 & & n.d. & $<5-5.04$ & 2.9 & & n.d. & $1.3-2.7$ & 1.7 \\
\hline PTT & n.d.-2.5 & & $2.5-9.4$ & 5.8 & $<5-6.6$ & 4.8 & $<1-1.1$ & 0.9 & & n.d. \\
\hline ITAM & & n.d. & & n.d. & & n.d. & & n.d. & & n.d. \\
\hline M1 & $5.6-9.4$ & 7.8 & $2.5-5.2$ & 2.8 & $<5-5.9$ & 4.0 & & $<1$ & $11-19$ & 16 \\
\hline M2 & $6.9-185$ & 10.6 & 2.5 & 2.5 & $<5-5.8$ & 3.6 & & n.d. & $11-29$ & 16 \\
\hline M3 & $2.5-7.5$ & 5.3 & $2.5-6.4$ & 3.9 & $<5-5.6$ & 3.3 & & $<1$ & $<6-20$ & 9.9 \\
\hline Japan [25] & $<0.2-1.1$ & & $0.1-1.3$ & & $0.2-1.2$ & & $<0.2-0.3$ & & & $\mathrm{n} / \mathrm{a}$ \\
\hline England [18 & $\mathrm{n} / \mathrm{p}-4.0$ & $0.6^{*}$ & $\mathrm{n} / \mathrm{p}-2.1$ & $0.5^{*}$ & & $\mathrm{n} / \mathrm{a}$ & $\mathrm{n} / \mathrm{p}-1$ & $0.4^{*}$ & & $\mathrm{n} / \mathrm{a}$ \\
\hline Australia[27] & $\mathrm{n} / \mathrm{p}-1.7$ & & $\mathrm{n} / \mathrm{p}-0.6$ & & & $\mathrm{n} / \mathrm{a}$ & & $\mathrm{n} / \mathrm{a}$ & & $\mathrm{n} / \mathrm{a}$ \\
\hline Greece[29] & & $\mathrm{n} / \mathrm{a}$ & $0.3-2.8$ & & & $\mathrm{n} / \mathrm{a}$ & & $\mathrm{n} / \mathrm{a}$ & & $\mathrm{n} / \mathrm{a}$ \\
\hline $\begin{array}{l}\text { Shenzen, } \\
\text { China [23] }\end{array}$ & & $\mathrm{n} / \mathrm{p}$ & $0.3-1.6$ & & & $0.4^{*}$ & & $\mathrm{n} / \mathrm{a}$ & & $\mathrm{n} / \mathrm{a}$ \\
\hline
\end{tabular}

n/a: compound not analyzed; n.d.: compound not detected; n/p: data not available.

$\mathrm{x}$ : average value, $*$ : median value.

[25] - Tap water from 12 chorine-based DWTP distribution systems (Only CACAM, BACAM, DCACAM., BCACAM, DBACAM, TCACAM were analyzed).

[18] - Finished water from 20 DWTPs (six DWTPs using chloramines and chlorine used in the remaining plants) (DCACAM, DBACAM and TCACAM were analyzed).

[27] - Finished waters from six DWTPs that use river surface water as source waters (5 DWTPs using chlorine and 1 DWTP using chloramine) $(n=6)$ and from the corresponding distribution systems $(n=6)$.

(CACAM, DCACAM, DBACAM were analyzed) CACACM was not detected.

[29] - Finished waters from 4 chlorine-based DWTPs (CACAM and DCACAM were analyzed), CACACM was not detected.

[23] Tap water from a chlorine-based DWTP distribution system ( $\mathrm{n}=132$ different locations)

(DCACAM, BCACAM, DBACAM, TCACAM were analyzed). 
Table S9 - Range and average (x) concentration (in $\mu \mathrm{g} / \mathrm{L}$ ) of the HANs detected in the investigated DBP mixtures and values reported in the literature for these DBPs in other drinking water supply systems.

\begin{tabular}{|c|c|c|c|c|c|c|c|c|}
\hline & \multicolumn{2}{|c|}{ CAN } & \multicolumn{2}{|c|}{ BAN } & \multicolumn{2}{|c|}{ DCAN } & \multicolumn{2}{|c|}{ DBAN } \\
\hline & Range & $x$ & Range & $x$ & Range & $x$ & Range & $x$ \\
\hline PTLL & & n.d. & $0.1-0.4$ & 0.3 & $0.2-0.3$ & 0.2 & $3.0-7.8$ & 5.8 \\
\hline $\begin{array}{l}\text { PTT } \\
\end{array}$ & & n.d. & & $<0.3$ & $0.7-1.3$ & 1.1 & $0.6-0.8$ & 0.8 \\
\hline ITAM & & n.d. & & n.d. & & n.d. & $0.3-0.4$ & 0.3 \\
\hline M1 & & $<0.25$ & $0.3-0.4$ & 0.3 & $0.2-0.6$ & 0.4 & $2.8-4.5$ & 3.7 \\
\hline$\overline{\mathrm{M} 2}$ & & n.d. & $0.3-0.5$ & 0.4 & $<0.1-0.2$ & 0.1 & $4.2-6.7$ & 5.5 \\
\hline M3 & & $<0.25$ & $<0.3-0.3$ & 0.2 & $0.2-0.7$ & 0.5 & $0.6-2.1$ & 1.4 \\
\hline US [32] & n.d. -0.9 & & n.d. -0.2 & & $2.0-6$ & & n.d.- -0.6 & \\
\hline UK [18] & $\mathrm{n} / \mathrm{p}-0.6$ & $0.6^{*}$ & $\mathrm{n} / \mathrm{p}-0.2$ & $0.2 *$ & $\mathrm{n} / \mathrm{p}$ & $3.2 *$ & $\mathrm{n} / \mathrm{p}-5.8$ & $1 *$ \\
\hline Australia [27] & $\mathrm{n} / \mathrm{p}-0.1$ & & $\mathrm{n} / \mathrm{p}-0.4$ & & $\mathrm{n} / \mathrm{p}-4.4$ & & $\mathrm{n} / \mathrm{p}-1.3$ & \\
\hline $\begin{array}{l}\text { Canada [22] } \\
\end{array}$ & & $\mathrm{n} / \mathrm{a}$ & & $\mathrm{n} / \mathrm{a}$ & $0.3-6.1$ & & $0.01-0.1$ & \\
\hline $\begin{array}{l}\text { Shenzen, } \\
\text { China [23] }\end{array}$ & & $\mathrm{n} / \mathrm{a}$ & & $\mathrm{n} / \mathrm{a}$ & 3.7(Max) & & & $\mathrm{n} / \mathrm{p}$ \\
\hline China [20] & n.d-34 & 2.7 & n.d.-21 & 2.5 & n.d.-6.7 & 1.3 & n.d.-4.1 & 1.6 \\
\hline
\end{tabular}

n/a: compound not analyzed; n.d.: compound not detected; n/p: data not provided.

$\mathrm{x}$ : average value, $*$ : median value.

[32] - Finished water from one DWTP using chlorine (Plant \#4, n=5) (BCAN 0.2-2, BDCAN, DBCAN, and TBAN were only detected in $n=2)$.

[18] - Finished water of 20 DWTPs (6 DWTPs used chloramine and chlorine was used in the remaining DWTPs).

[27] - Finished waters from six DWTPs that use river surface water as source waters (5 DWTPs using chlorine and 1 DWTP using chloramine) $(n=6)$ y from the corresponding distribution systems $(n=6)$.

[22] - Finished water and from the distribution network of 25 chlorine-based DWTP (**only DCAN, DBAN, BCAN and TCAN were analyzed, BCAN=0.2 ppb).

[23] Tap water from a chlorine-based DWTP distribution system ( $\mathrm{n}=132$ different locations).

[20] - Finished water from 70 DWTPs (7 DWTPs used chloramines, 3 DWTPs used $\mathrm{ClO}_{2}$ and chlorine was used in the remaining ones) - BCAN (n.d.- 21,04) and IAN (n.d.-4,2) were also analyzed. 
Table 9 (cont.) - Range and average (X) concentration (in $\mu \mathrm{g} / \mathrm{L}$ ) of the HANs detected in the investigated DBP mixtures and values reported in the literature for these DBPs in other drinking water supply systems.

\begin{tabular}{|c|c|c|c|c|c|c|c|c|}
\hline & \multicolumn{2}{|c|}{ TCAN } & \multicolumn{2}{|c|}{ BDCAN } & \multicolumn{2}{|c|}{ DBCAN } & \multicolumn{2}{|c|}{ TBAN } \\
\hline & Range & $x$ & Range & $x$ & Range & $x$ & Range & $x$ \\
\hline PTLL & & n.d. & & n.d. & & n.d. & & $<0.5$ \\
\hline PTT & & $<0.10$ & $1.1-1.1$ & 1.1 & & 1.1 & & n.d. \\
\hline ITAM & & n.d. & & n.d. & & n.d. & & n.d. \\
\hline M1 & & $<0.10$ & & n.d. & & n.d. & & n.d. \\
\hline M2 & & n.d. & & n.d. & & n.d. & & n.d. \\
\hline M3 & & $<0.10$ & & n.d. & & n.d. & & n.d. \\
\hline US [32] & n.d. -0.1 & & & n.d. & & n.d. & & n.d. \\
\hline UK [18] & & $\mathrm{n} / \mathrm{a}$ & & $\mathrm{n} / \mathrm{a}$ & $\mathrm{n} / \mathrm{p}-0.7$ & $0.2 *$ & & $\mathrm{n} / \mathrm{a}$ \\
\hline Australia [27] & $\mathrm{n} / \mathrm{p} 1.3$ & & & $\mathrm{n} / \mathrm{a}$ & & $\mathrm{n} / \mathrm{a}$ & & $\mathrm{n} / \mathrm{a}$ \\
\hline$\overline{\text { Canada [22] }}$ & $0.0-0.2$ & & & $\mathrm{n} / \mathrm{a}$ & & $\mathrm{n} / \mathrm{a}$ & & $\mathrm{n} / \mathrm{a}$ \\
\hline $\begin{array}{l}\text { Shenzen. } \\
\text { China [23] }\end{array}$ & & $\mathrm{n} / \mathrm{p}$ & & $\mathrm{n} / \mathrm{a}$ & & $\mathrm{n} / \mathrm{a}$ & & $\mathrm{n} / \mathrm{a}$ \\
\hline China [20] & n.d.-1.0 & 0.2 & & $\mathrm{n} / \mathrm{a}$ & & $\mathrm{n} / \mathrm{a}$ & & $\mathrm{n} / \mathrm{a}$ \\
\hline
\end{tabular}

n/a: compound not analyzed; n.d.: compound not detected; $n / p$ : data not provided.

$\mathrm{x}$ : average value, *: median value.

[32] - Finished water from one DWTP using chlorine (Plant \#4, n=5) (BCAN 0.2-2, BDCAN, DBCAN, and TBAN were only detected in $n=2)$.

[18] - Finished water of 20 DWTPs (6 DWTPs used chloramine and chlorine was used in the remaining DWTPs).

[27] - Finished waters from six DWTPs that use river surface water as source waters (5 DWTPs using chlorine and 1 DWTP using chloramine) $(n=6)$ y from the corresponding distribution systems $(n=6)$.

[22] - Finished water and from the distribution network of 25 chlorine-based DWTP (**only DCAN, DBAN, BCAN and TCAN were analyzed, BCAN=0.2 ppb).

[23] Tap water from a chlorine-based DWTP distribution system ( $\mathrm{n}=132$ different locations).

[20] - Finished water from 70 DWTPs (7 DWTPs used chloramines, 3 DWTPs used $\mathrm{ClO}_{2}$ and chlorine was used in the remaining ones) - BCAN (n.d.- 21,04) and IAN (n.d.-4,2) were also analyzed. 
Table 10 - Range and average (x) concentration (in $\mu \mathrm{g} / \mathrm{L}$ ) of THALs in the investigated DBP mixtures and values reported in the literature for this DBP class in other drinking water supply systems.

\begin{tabular}{|c|c|c|c|c|c|c|c|c|}
\hline & \multicolumn{2}{|c|}{ TCAL } & \multicolumn{2}{|c|}{ BDCAL } & \multicolumn{2}{|c|}{ DBCAL } & \multicolumn{2}{|c|}{ TBAL } \\
\hline & Range & $x$ & Range & $x$ & Range & $x$ & Range & $x$ \\
\hline PTLL & - & $<0.25$ & $<0.50-1.02$ & 0.75 & $0.92-3.13$ & 2.29 & $0.50-3.13$ & 1.4 \\
\hline PTT & $1.0-7.9$ & 3.9 & $<0.50-1.81$ & 1.15 & $0.85-0.99$ & 0.88 & - & $<0.5$ \\
\hline ITAM & - & n.d. & - & n.d. & - & n.d. & - & n.d. \\
\hline M1 & $0.9-2.1$ & 1.4 & $0.50-1.83$ & 1.29 & $0.73-2.63$ & 1.95 & $0.27-0.80$ & 0.6 \\
\hline M2 & - & n.d. & $0.73-0.94$ & 0.86 & $0.98-2.73$ & 2.22 & $0.31-1.53$ & 1.2 \\
\hline M3 & $1.4-3.2$ & 1.96 & $0.50-2.07$ & 1.27 & $0.69-1.78$ & 1.29 & $0.39-0.43$ & 0.4 \\
\hline US [32] & 2.0.-14** & $1 *$ & & $\mathrm{n} / \mathrm{a}$ & & $\mathrm{n} / \mathrm{a}$ & & n.d. \\
\hline US [35] & $0.1-4.1$ & & $1.1-2.2$ & & $0.3-2.7$ & & $0.5-13$ & \\
\hline Canada [26] & $1.8-12$ & & $0.3-7.2$ & & $2.5-12$ & & n.d. -1.5 & \\
\hline $\begin{array}{l}\text { Athens, } \\
\text { Greece [21] }\end{array}$ & $0.3-11$ & & & $\mathrm{n} / \mathrm{a}$ & & $\mathrm{n} / \mathrm{a}$ & & $\mathrm{n} / \mathrm{a}$ \\
\hline $\begin{array}{l}\text { Shenzen } \\
\text { China [23] }\end{array}$ & & $3.2 *$ & & $0.2 *$ & & $0.1^{*}$ & & $\mathrm{n} / \mathrm{a}$ \\
\hline
\end{tabular}

n/a: compound not analyzed; nd.: compound not detected, $\mathrm{x}$ : average value, $*$ : median value.

[32] - Finished water from one DWTP using chlorine (Plant \#4, n=5) ** Bromochloroacetaldehyde + chloral.

[35] Finished waters from 7 DWTPs (2 DWTPs used chlorine and 5 DWTPs used chloramines).

[26] Finished waters from 3 chlorine-based DWTPs.

[21] Finished waters from 4 chlorine-based DWTP.

[23] Tap water of a chlorine-based DWTP distribution system ( $n=122$ different locations). 
Table 11 - Range and average ( $\mathrm{x}$ ) concentration (in $\mu \mathrm{g} / \mathrm{L}$ ) of the I-THMs detected in the investigated DBP mixtures and values reported in the literature for these DBPs in other drinking water supply systems.

\begin{tabular}{|c|c|c|c|c|c|c|c|c|}
\hline & \multicolumn{2}{|c|}{ DCIM } & \multicolumn{2}{|c|}{ BCIM } & \multicolumn{2}{|c|}{ DBIM } & \multicolumn{2}{|c|}{$\Sigma$ I-THMs } \\
\hline & Range & $x$ & Range & $x$ & Range & $x$ & Range & $x$ \\
\hline PTLL & - & n.d. & - & $<0.1$ & & $<0.3$ & & $<0.35$ \\
\hline PTT & $0.2-0.2$ & 0.2 & - & n.d. & & $<0.3$ & $0.3-0.3$ & 0.3 \\
\hline ITAM & - & n.d. & - & n.d. & & n.d. & & n.d. \\
\hline M1 & $0.1-0.1$ & 0.1 & - & $<0.1$ & & $<0.3$ & $0.3-0.3$ & 0.3 \\
\hline$\overline{\mathrm{M} 2}$ & - & n.d. & - & $<0.1$ & & $<0.3$ & & $<0.4$ \\
\hline M3 & $0.1-0.2$ & 0.1 & - & n.d & & $<0.3$ & $0.2-0.3$ & 0.3 \\
\hline US [28] & $0.1-5.7$ & 1.3 & $0.06-5.4$ & 0.8 & & $\mathrm{n} / \mathrm{a}$ & $0.09-7.8$ & \\
\hline US [32] & n.d. -1.0 & & & n.d. & & n.d. & & - \\
\hline China [20] & n.d.-3.8 & 1.1 & n.d.-1.1 & 1.4 & & n.d. & & \\
\hline $\begin{array}{l}\text { Barcelona, } \\
\text { Spain [19] }\end{array}$ & & n.d. & & n.d. & & n.d. & & n.d. \\
\hline $\begin{array}{l}\text { Limassol, } \\
\text { Cyprus [24] }\end{array}$ & $0.03-1.7$ & 0.6 & $<0.01-0.5$ & 0.1 & & $\mathrm{n} / \mathrm{a}$ & $0.04-1.8$ & 0.6 \\
\hline $\begin{array}{l}\text { Nicosia, } \\
\text { Cyprus [24] }\end{array}$ & $0.03-0.9$ & 0.5 & $0.01-0.2$ & 0.1 & & $\mathrm{n} / \mathrm{a}$ & $0.04-1.1$ & 0.6 \\
\hline
\end{tabular}

n/a: compound not analyzed; n.d.: compound not detected, $\mathrm{x}$ : average value.

[28] - Finished water of 23 DWTPs (21 DWTPs used chloramines and 2 DWPTs used chlorine as final disinfectant) - only DCIM and BCIM were analyzed.

[32] - Finished water from one DWTP using chlorine (Plant \#4, n=5) (TIM detected at $2 \mu \mathrm{g} / \mathrm{L}$ in only one sample).

[20] - Finished water from 70 DWTPs (7 DWTPs used chloramines, 3 DWTPs used $\mathrm{ClO}_{2}$ and chlorine was used in the remaining ones - only DCIM, BCIM, DBIM, and TIM were analyzed (TIM was not detected in any sample).

[19] - Tap water of a chlorine-based DWTP distribution system ( $\mathrm{n}=21)$.

[24] - Tap water of a chlorine-based DWTP distribution system $(\mathrm{n}=18)$.

[24] - Tap water of a chlorine-based DWTP distribution system $(n=20)$.

\subsubsection{DBP speciation}

THM4 and HAAs were the main DBP classes formed in all water matrices investigated, in agreement with literature reports on water disinfected with chlorine [36]. The THM4 formation potential of PTLL $(51 \mu \mathrm{g} / \mathrm{L}$ at $\mathrm{t}=0)$ was slightly higher than that of PTT (36 $\mu \mathrm{g} / \mathrm{L}$ at $\mathrm{t}=0$ ). Due to the bromide content in PTLL and its diluted mixtures, highly brominated species dominated the THM4 speciation pattern (tribromomethane (TBM) >dibromochloromethane $(\mathrm{DBCM})>$ bromodichloromethane $(\mathrm{BDCM})>$ trichloromethane 
(TCM)), whereas chlorinated species were dominant in PTT and M3 ( TCM $<$ BDCM $<$ DBCM $<$ TBM $)$. As regard HAAs, PTT $(70 \mu \mathrm{g} / \mathrm{L}$ at $\mathrm{t}=0)$ presented a slightly higher formation potential of this DBP class than PTLL $(65 \mu \mathrm{g} / \mathrm{L}$ at $\mathrm{t}=0)$. Similarly as for THM4, brominated species, with dibromoacetic acid (DBAA) as the most abundant one, also contributed the most to total HAAs concentrations in PTLL and its mixture M2; and chlorinated species, and in particular dichloroacetic acid (DCAA) and trichloroacetic acid (TCAA), were more relevant in PTT and M3 than in PTLL and its mixtures. Despite being the most abundant DBP classes, concentrations of THM4 and HAA5 in DWTP finished waters and their mixtures (at $\mathrm{t}=0$ ) were below the drinking water standards set at European and US level.

HACMs was the third most abundant class (3-28 $\mu \mathrm{g} / \mathrm{L})$. Main species formed in waters with high $\mathrm{Br}^{-}$content (PTLL, M1, and M2) were bromochloroacetamide (BCACM) and dibromoacetamide (DBACM). Although a relevant contribution of BCACM to total HACM levels was also observed in PTT and M3, dichloroacetamide (DCACM) was the most abundant species in these water matrices. Formation of DCAM and trichloroacetamide (TCACM) was exclusive of PTT and the mixtures that contained this matrix (M1 and M3).

As it was observed for HACMs, total HAN concentrations (1.4-8.5 $\mu \mathrm{g} / \mathrm{L})$ resulted mainly from dihalogenated species. Thus, dibromoacetonitrile (DBAN) was the main HAN species formed in PTLL and M2, and DCAN was the main HAN formed in PTT. All investigated water matrices had the potential to form Br-HANs. Although PTT showed the lowest potential in this respect, it was increased after its dilution with desalinated water (M3).

In the case of THALs (up to $8 \mu \mathrm{g} / \mathrm{L}$ in the investigated DBP mixtures), and similar to the other investigated DBP classes, PTLL and its mixture with desalinated water (M2) formed mainly brominated species (dibromochloroacetaldehyde (DBCAL)>tribromoacetaldehyde (TBAL)>bromodichloroacetaldehyde (BDCAL)). Chloral was the main THALs formed in PTT and M3.

The formation of iodinated DBPs (I-THMs, iodoacids, and iodoacetonitrile) was very minor. This could be attributed to the low $\mathrm{I}^{-}$levels in both source river waters (after $40 \%$ of brackish Llobregat River water treated with EDR), and the use of chlorine as disinfectant. Free chlorine contributes to rapidly oxidize the hypoiodous acid (oxidative species formed after reaction of $\mathrm{I}^{-}$and free chlorine) to iodate so that the former is not available in the 
solution to further react with water OM [37, 38]. I-THM formation potential of investigated waters at $\mathrm{t}=0$ ranged between 0.18 and $0.31 \mu \mathrm{g} / \mathrm{L}$, being dichloroiodomethane (DCIM) the ITHM detected at the highest levels. As for iodoacids, only iodoacetic acid (IAA) was found in PTT and its mixtures (M1 and M3), always below its MRL (2.5 $\mu \mathrm{g} / \mathrm{L})$ Iodoacetonitrile (IAN) was not detected in any investigated DBP mixture.

\subsubsection{Effect of residence time and temperature in DBPFP.}

The evolution of the DBPFP of the different investigated matrices as a function of water residence time (chlorine contact time) and water temperature is shown in Figures 3-7. It was assessed for all DBP classes but for I-THMs, due to the low concentrations formed.

The THM4 formation potential, and particularly that of brominated species, increased in all investigated water matrices with increasing residence time and temperature (Fig. 9). The highest increase occurred during the first $24 \mathrm{~h}$ of residence time at $30^{\circ} \mathrm{C}$. In most cases, the formation potential of THM 4 reached a plateau at $30^{\circ} \mathrm{C}$ after $48 \mathrm{~h}$. In contrast, THM4 were continuously formed at $15^{\circ} \mathrm{C}$. Only in PTLL and only under continuous extreme water temperatures $\left(30^{\circ} \mathrm{C}\right.$ ) and extremely long residence times (more than $92 \mathrm{~h}$ if we also consider the tank hydraulic residence time), the formation of THM4 was above European standards.

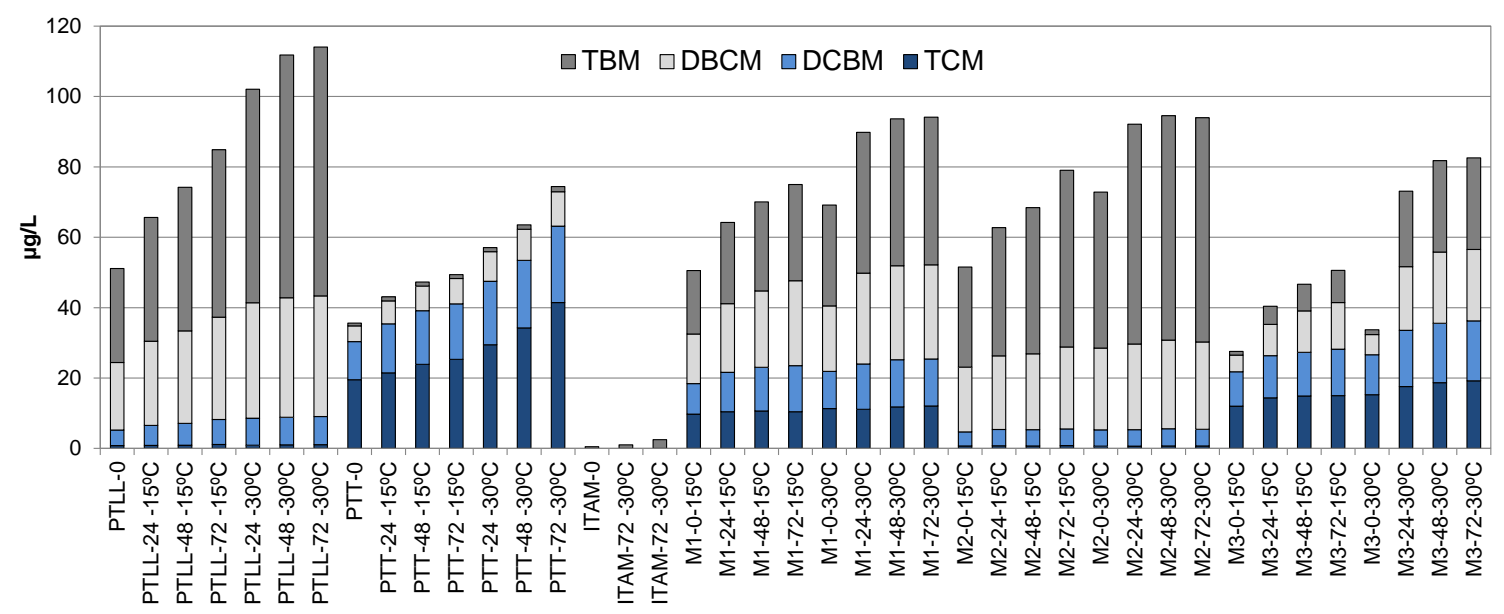

Figure 9. Formation potential of regulated trihalomethanes (THM4) of the water matrices at investigated temperatures and residence times. 
Formation of HAA was also enhanced at high water temperature $\left(30^{\circ} \mathrm{C}\right)$ (Fig. 10). As for the residence time, HAA formation was overall maintained during $24-48 \mathrm{~h}$ and decreased afterward. For instance, in all mixtures but in $\mathrm{M} 1$ at $30^{\circ} \mathrm{C}$ and $\mathrm{M} 2$ at $15^{\circ} \mathrm{C}$ HAA concentrations after $72 \mathrm{~h}$ were $\pm 18 \%$ of the initial values. The temperature effect on the formation of the different HAA species is confounded by the residence time effect and the HAA precursors present in each matrix. So that, different formation potential patterns of HAAs species were observed as a function of time within the same matrix at different temperatures.

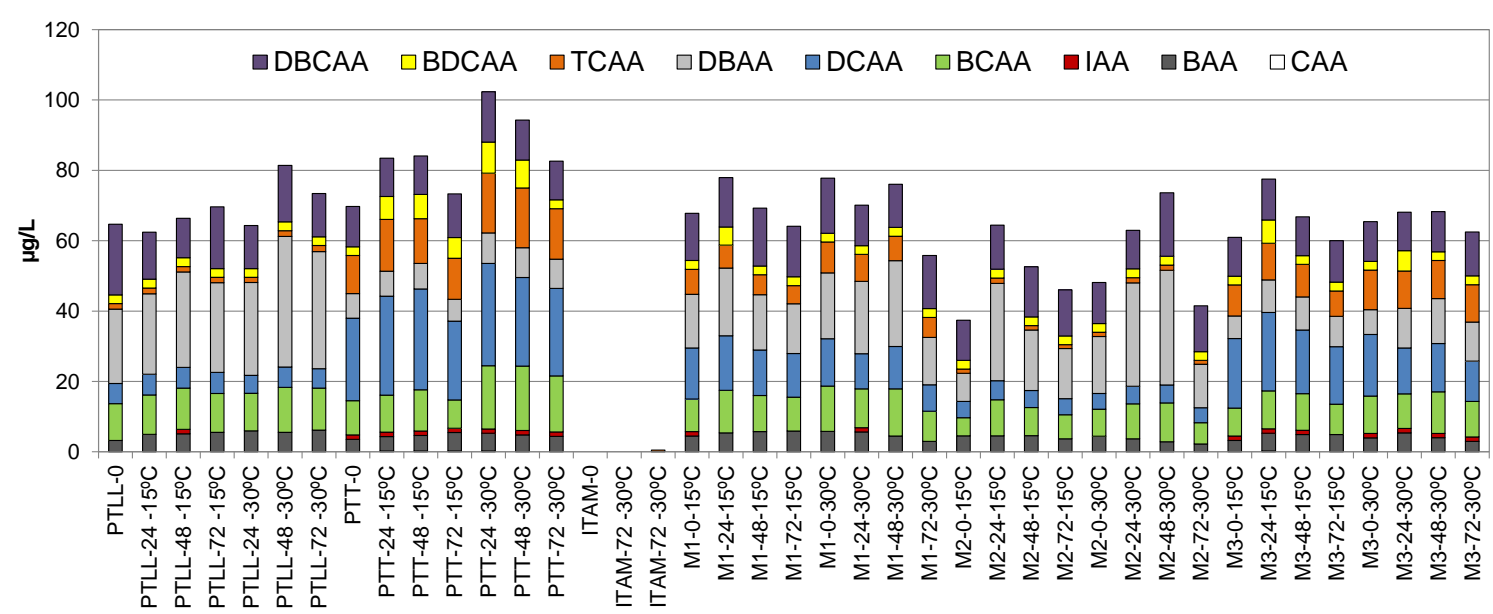

Figure 10. Formation potential of haloacetic acids (HAAs) of the water matrices at investigated temperatures and residence times.

Overall, the HACM formation potential increased at high water temperatures (Fig 11). The formation of the main HACM species detected in the DBP mixtures was maintained or even also increased in time.

HAN formation was enhanced at high water temperature; however, this increase was more noticeable in PTLL than in PTT (Fig. 12). As for HAAs, their formation was maintained in time or decreased after $48 \mathrm{~h}$ in most cases. DBAN formation was enhanced by both water temperature and residence time. The formation potential of DCAN was increased or maintained at $15^{\circ} \mathrm{C}$ and decreased at $30^{\circ} \mathrm{C}$ at increasing residence time.

THAL formation was reduced at elevated water temperatures, due to the instability of Br-THALs, since chloral formation was enhanced with time at high water temperature (Fig. 13). 


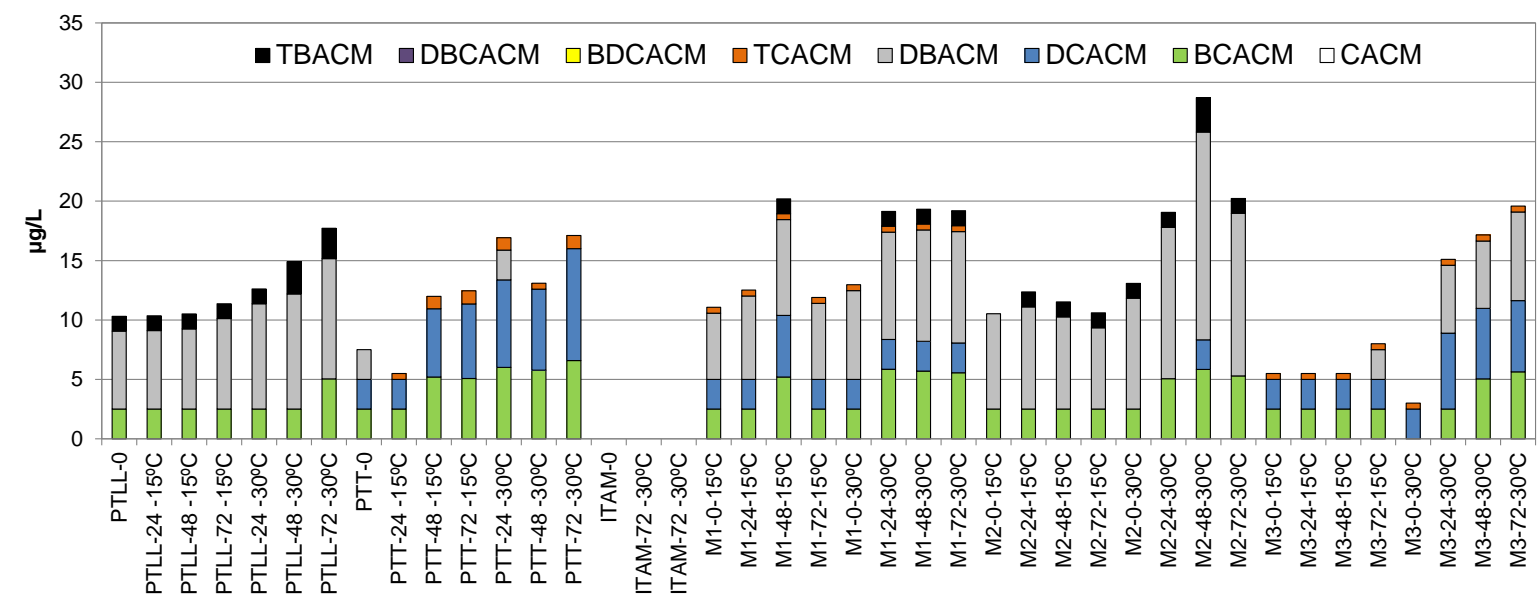

Figure 11. Formation potential of haloacetamides (HACMs) of the water matrices at investigated temperatures and residence times.

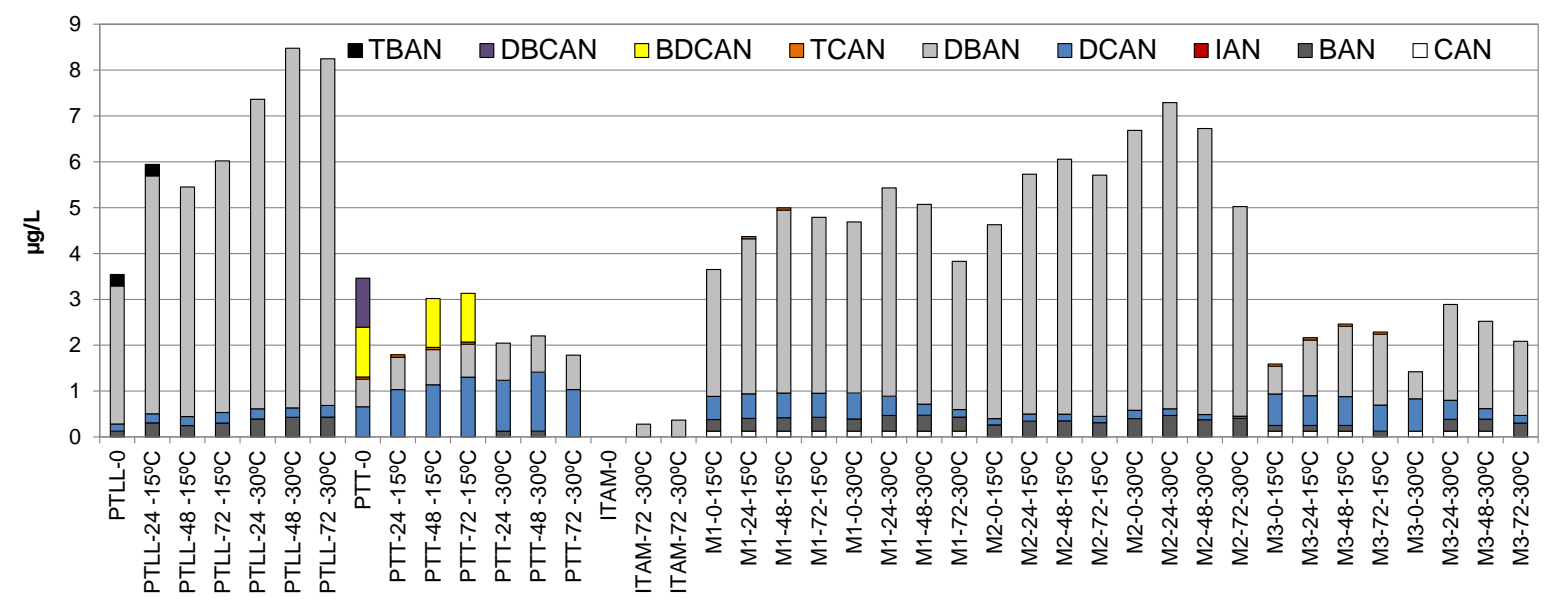

Figure 12. Formation potential of haloacetonitriles (HANs) of the water matrices at investigated temperatures and residence times.

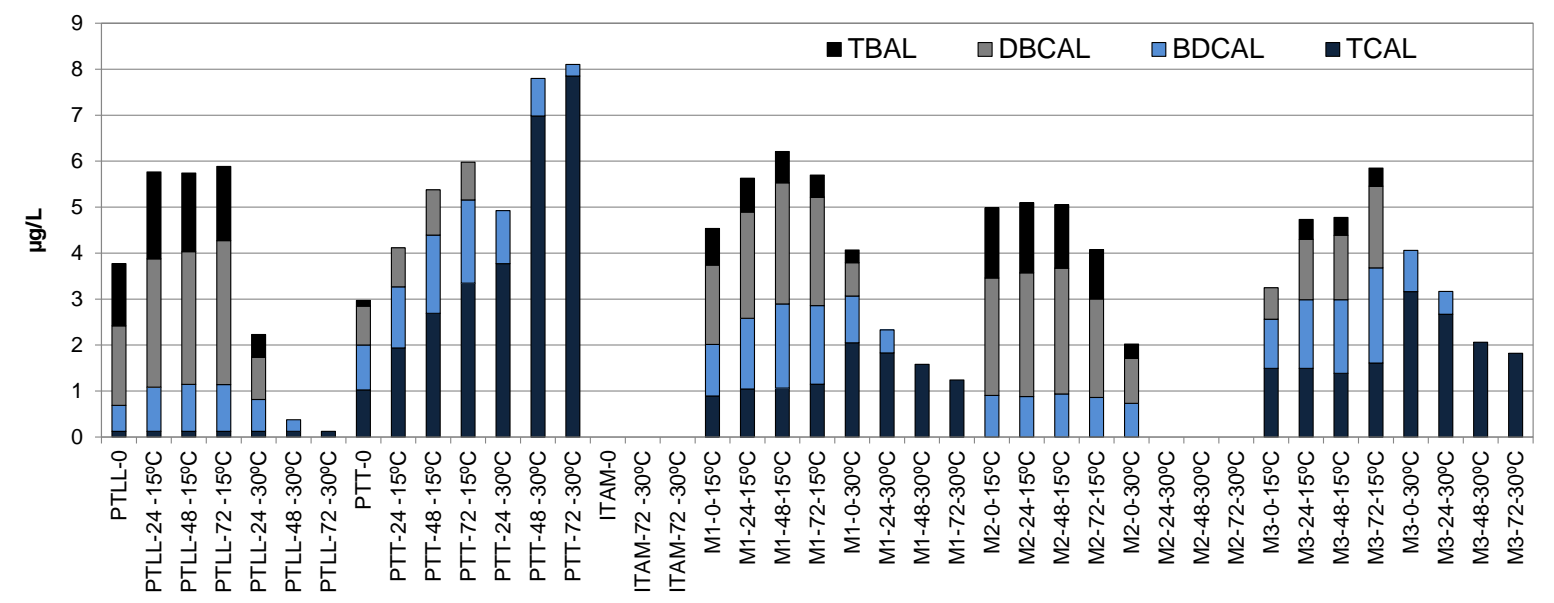

Figure 13. Formation potential of trihalogenated acetaldehydes (THALs) of the water matrices at investigated temperatures and residence times. 


\subsection{Toxicity risk assessment}

Figure 14 shows the cytotoxic and genotoxic potency, expressed as IAA cyto- and genotoxic equivalent concentrations, of the DBP mixtures generated in finished drinking waters and in their mixtures. The contribution of the different DBP classes to the total toxic potency of each DBP mixture at $\mathrm{t}=0$ is summarized in Figure 15.

PTLL was about two times more cytotoxic than PTT, which could be attributed to its high content of N-containing DBPs, as HACMs and HANs were the most cytotoxic DBP classes. Because of this, the cytotoxic potency of M1 and M2 was also higher than that of M3. HAAs was the DBP class that contributed to more than $50 \%$ of the total cytotoxic potency of PTT and M3 (see Figure 15-a).

Genotoxic potencies were very similar in PTLL, PTT, and M3, and slightly higher than M1 and M2. Taking into account that THMs and I-THMs were not included in the genotoxicity assessment, HAAs followed by HANs were the DBP classes that contributed the most to the genotoxic potency of the investigated DBP mixtures (see Figure 15-c).

Overall, Br-DBPs (DBPs containing at least one bromine atom) was the chemical class responsible for the cytotoxicity and genotoxicity of the DBP mixtures (see Figures 15-b and 15-d). The contribution of I-DBPs (DBPs containing at least one iodine atom) to the overall mixture toxicity was also relevant when they were present in the mixture, in spite of their low concentrations.

The quantitative approach here described to evaluate the toxicity of the DBP mixtures can be used as a "screening" tool to rank mixtures and compounds in the mixture. It does not reflect the real toxicity of the mixture, since it is based on in vitro toxicity responses of individual DBPs, and thus, the real amount of chemical that may reach cells is overlooked in this approach, as well as synergies and antagonisms in this respect that may occur in the mixture. The fact of considering DBP concentrations in drinking water completely bioavailable to the cells results in an overestimation of the toxicity of the DBP mixture. Moreover, the extrapolation of in vitro observations to intact organisms has different sources of uncertainty associated. 


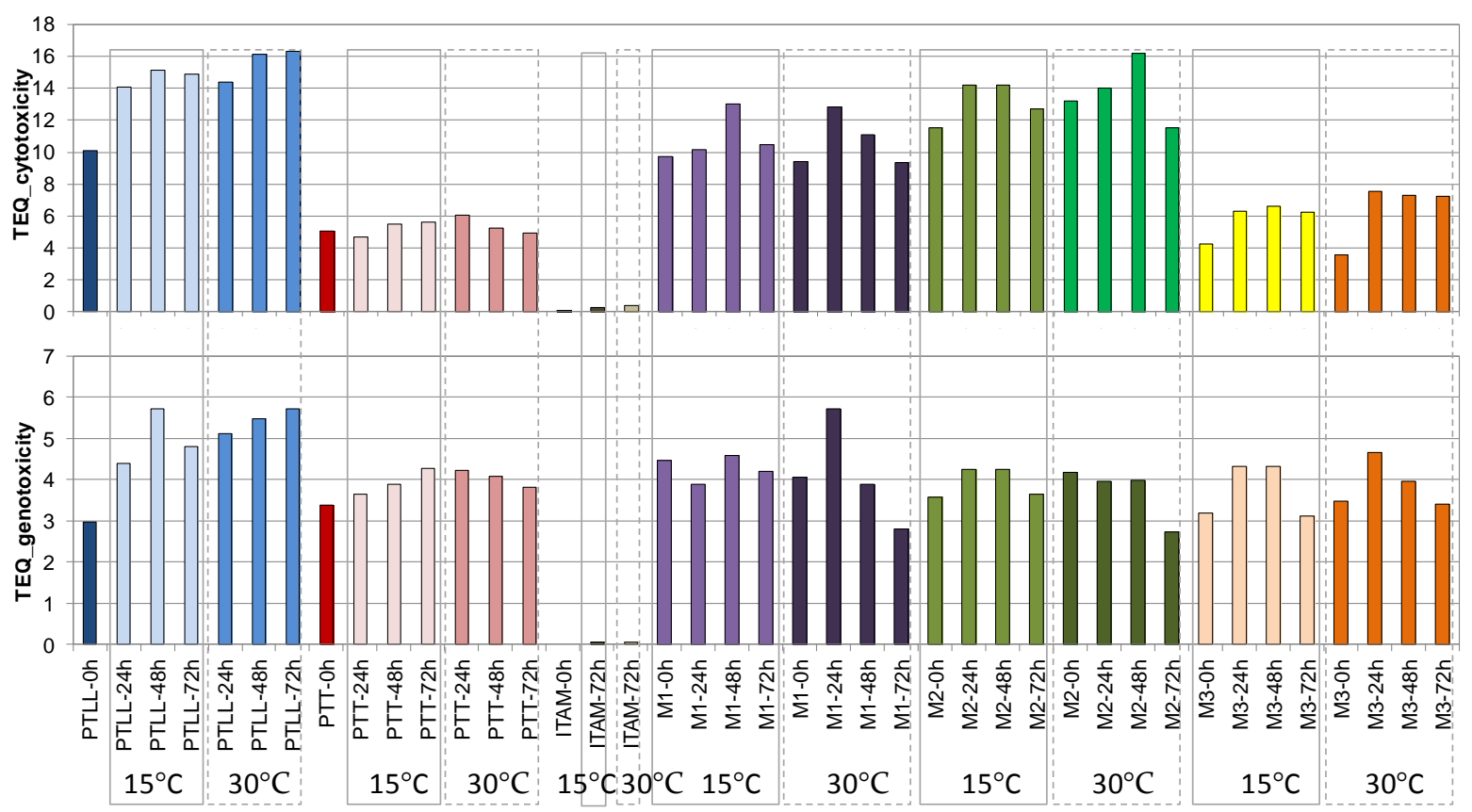

Figure 14. Cytotoxic and genotoxic equivalent concentrations of the DBP mixtures.
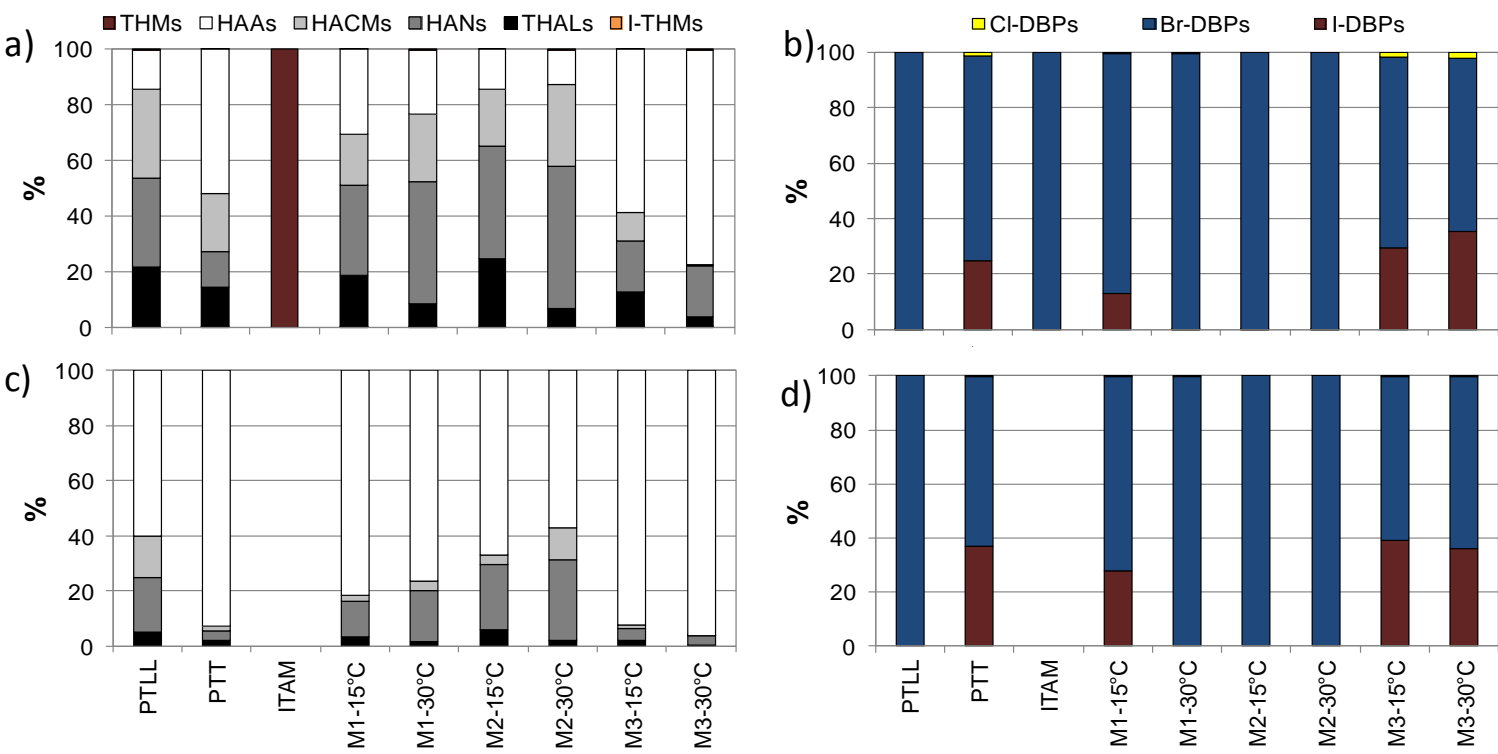

Figure 15. Contribution of the different DBP classes to the total cytotoxicity ( $a$ and $b$ ) and genotoxicity (c and d) of the DBP mixtures investigated. 


\section{Conclusions}

This study provides information on the DBPFP of the drinking water supplied to the city of Barcelona and its metropolitan area and the risk associated, in terms of genotoxicity and cytotoxicity of the DBP mixtures formed; which contributes to progress in the better management of this large drinking water supply network and protect human health.

Proper drinking water treatment of high bromide source water (Llobregat River water) was effective in reducing DBP levels in drinking water and keeping THM4 levels below drinking water standards. However, Br-DBPs were still the main species formed. The blend of both DWTP finished waters increased the original DBPFP of PTT and reduced that of PTLL. The dilution of DWTP finished waters with desalinated water reduced their overall DBPFP, but enhanced the potential of PTT to form Br-DBPs at long chlorine contact times. The formation potential of iodinated DBPs was very low due to the low content of iodide of all source waters and the use of chlorine as disinfectant. Overall, DBP concentrations measured were similar to those reported in the literature for other drinking water supply systems.

Toxicity assessment pointed out the toxicity forcing agents; however, toxic equivalent concentrations obtained are likely to be higher than real because drinking water concentrations were considered to be fully bioavailable to the cells. HAA and N-DBPs, and overall, Br-DBPs, were identified as the main chemical classes responsible for potential cytotoxic and genotoxic effects of the mixtures. Further reduction of Br-DBPs, for instance, by further removing bromide in source waters or minimizing the residence time of the mixtures in the distribution system would contribute to reducing the toxic potency of the DBPs mixture. In this regard, treatment of different amounts of the source water with EDR at the Llobregat DWTP has been proven as an effective measure to remove bromide from the source water, and thus, keep DBP levels and their associated toxicity low. To date, the amount of working EDR units are modulated according to the quality of the source water arriving at the plant so that the lowest formation potential of DBPs is achieved considering the operational and economic feasibility of the water treatment process. All EDR installed units could be implemented at full capacity if required

Overall, our findings indicate that desalinated water is the drinking water resource with the highest chemical and toxicological qualities. However, the exclusive use of desalinated water to supply drinking water to such large population, i.e., 4.5 million people, would not be economically feasible. Furthermore, desalinated water needs to be blended with other DWTP 
products in order to improve its organoleptic properties and consumer's acceptance.

Future studies will focus on evaluating the maximum DBPFP, after forcing disinfection conditions, of the source waters after each step involved in the different drinking water treatment facilities to evaluate the risk associated in case of failure of any of the steps, and the potential contribution of the biofilm present in the drinking water distribution pipes to the DBPFP of the water, aspect not considered in the present study.

\section{Acknowledgments}

C.P. acknowledges support from the Secretary for Universities and Research of the Ministry of Economy and Knowledge of the Government of Catalonia and the COFUND Programme of the Marie Curie Actions of the EU's FP7 (2014 BP_B00064). This work was financially supported by the Government of Catalonia (Consolidated Research Groups 2017 SGR 1404Water and Soil Quality Unit).

\section{References}

[1] J.J. Rook, Formation of haloforms during chlorination of natural waters, Journal of Water Treatment Examination, 23 (1974) 234-243.

[2] T.A. Bellar, J.J. Lichtenberg, R.C. Kroner, Occurrence of organohalides in chlorinated drinking waters, Journal / American Water Works Association, 66 (1974) 703-706.

[3] USEPA, EPA Drinking Water Guidance on Disinfection By-Products. Advice Note No. 4, version 2. Disinfection by-products in drinking water. Available a https://goo.gl/ea8YsU. Accessed September 2017., (2012).

[4] 98/83/EC, Council Directive 98/83/EC of 3 November 1998 on the quality of water intended for human consumption. Official Journal of the European Communities, L330/32. [5] G. Hua, D.A. Reckhow, Factors affecting the formation of disinfection byproducts during chlorination and chloramination, 2005 Water Quality Technology Conference Proceedings, WQTC 2005, (2005).

[6] G. Hua, D.A. Reckhow, J. Kim, Effect of bromide and iodide ions on the formation and speciation of disinfection byproducts during chlorination, Environmental Science and Technology, 40 (2006) 3050-3056.

[7] S.W. Krasner, The formation and control of emerging disinfection by-products of health concern, Philosophical Transactions of the Royal Society A: Mathematical, Physical and 
Engineering Sciences, 367 (2009) 4077-4095.

[8] S.D. Richardson, C. Postigo, Formation of DBPs: State of the Science, ACS Symposium Series, (2015), pp. 189-214.

[9] E.D. Wagner, M.J. Plewa, CHO cell cytotoxicity and genotoxicity analyses of disinfection by-products: An updated review, Journal of Environmental Sciences (China), (2017).

[10] C.M. Villanueva, K.P. Cantor, J.O. Grimalt, N. Malats, D. Silverman, A. Tardon, R. Garcia-Closas, C. Serra, A. Carrato, G. Castano-Vinyals, R. Marcos, N. Rothman, F.X. Real, M. Dosemeci, M. Kogevinas, Bladder cancer and exposure to water disinfection by-products through ingestion, bathing, showering, and swimming in pools, Am J Epidemiol, 165 (2007) 148-156.

[11] C.M. Villanueva, E. Gracia-Lavedan, J. Ibarluzea, L. Santa Marina, F. Ballester, S. Llop, A. Tardon, M.F. Fernandez, C. Freire, F. Goni, X. Basagana, M. Kogevinas, J.O. Grimalt, J. Sunyer, I. Project, Exposure to trihalomethanes through different water uses and birth weight, small for gestational age, and preterm delivery in Spain, Environ Health Perspect, 119 (2011) 1824-1830.

[12] S.H. Safe, Hazard and risk assessment of chemical mixtures using the toxic equivalency factor approach, Environmental Health Perspectives, 106 (1998) 1051-1058.

[13] T. Karanfil, M.A. Schlautman, I. Erdogan, Survey of DOC and UV measurement practices with implications for SUVA determination, Journal / American Water Works Association, 94 (2002) 68-80.

[14] J.L. Weishaar, G.R. Aiken, B.A. Bergamaschi, M.S. Fram, R. Fujii, K. Mopper, Evaluation of Specific Ultraviolet Absorbance as an Indicator of the Chemical Composition and Reactivity of Dissolved Organic Carbon, Environmental Science \& Technology, 37 (2003) 4702-4708.

[15] T. Bond, J. Huang, M.R. Templeton, N. Graham, Occurrence and control of nitrogenous disinfection by-products in drinking water - A review, Water Research, 45 (2011) 43414354.

[16] A.A. Stevens, L.A. Moore, R.J. Miltner, Formation and Control of Non-Trihalomethane Disinfection By-products, Journal (American Water Works Association), 81 (1989) 54-60. [17] P. Roccaro, G.V. Korshin, D. Cook, C.W.K. Chow, M. Drikas, Effects of pH on the speciation coefficients in models of bromide influence on the formation of trihalomethanes and haloacetic acids, Water Research, 62 (2014) 117-126.

[18] T. Bond, M.R. Templeton, N.H. Mokhtar Kamal, N. Graham, R. Kanda, Nitrogenous 
disinfection byproducts in English drinking water supply systems: Occurrence, bromine substitution and correlation analysis, Water Research, 85 (2015) 85-94.

[19] B. Cancho, F. Ventura, M. Galceran, A. Diaz, S. Ricart, Determination, synthesis and survey of iodinated trihalomethanes in water treatment processes, Water Research, 34 (2000) 3380-3390.

[20] H. Ding, L. Meng, H. Zhang, J. Yu, W. An, J. Hu, M. Yang, Occurrence, profiling and prioritization of halogenated disinfection by-products in drinking water of China, Environmental Sciences: Processes and Impacts, 15 (2013) 1424-1429.

[21] S.K. Golfinopoulos, A.D. Nikolaou, Survey of disinfection by-products in drinking water in Athens, Greece, Desalination, 176 (2005) 13-24.

[22] S. Guilherme, M.J. Rodriguez, Occurrence of regulated and non-regulated disinfection by-products in small drinking water systems, Chemosphere, 117 (2014) 425-432.

[23] H. Huang, H. Zhu, W. Gan, X. Chen, X. Yang, Occurrence of nitrogenous and carbonaceous disinfection byproducts in drinking water distributed in Shenzhen, China, Chemosphere, 188 (2017) 257-264.

[24] P. Ioannou, P. Charisiadis, S.S. Andra, K.C. Makris, Occurrence and variability of iodinated trihalomethanes concentrations within two drinking-water distribution networks, Science of the Total Environment, 543 (2016) 505-513.

[25] K. Kosaka, K. Ohkubo, M. Akiba, Occurrence and formation of haloacetamides from chlorination at water purification plants across Japan, Water Research, 106 (2016) 470-476. [26] B.K. Koudjonou, G.L. LeBel, Halogenated acetaldehydes: Analysis, stability and fate in drinking water, Chemosphere, 64 (2006) 795-802.

[27] D. Liew, K.L. Linge, C.A. Joll, Formation of nitrogenous disinfection by-products in 10 chlorinated and chloraminated drinking water supply systems, Environmental Monitoring and Assessment, 188 (2016) 518.

[28] S.D. Richardson, F. Fasano, J.J. Ellington, F.G. Crumley, K.M. Buettner, J.J. Evans, B.C. Blount, L.K. Silva, T.J. Waite, G.W. Luther, A.B. McKague, R.J. Miltner, E.D. Wagner, M.J. Plewa, Occurrence and Mammalian Cell Toxicity of Iodinated Disinfection Byproducts in Drinking Water, Environmental Science \& Technology, 42 (2008) 8330-8338.

[29] S.A. Samios, S.K. Golfinopoulos, Haloacetamides in the Drinking Water of Athens, Greece: Determination and Degradation, Analytical Letters, 49 (2016) 1091-1101.

[30] V. Uyak, S. Soylu, T. Topal, N. Karapinar, K. Ozdemir, S. Ozaydin, E. Avsar, Spatial and Seasonal Variations of Disinfection Byproducts (DBPs) in Drinking Water Distribution Systems of Istanbul City, Turkey, Environmental Forensics, 15 (2014) 190-205. 
[31] O.I. Vallejo-Vargas, L. Beltrán, P. Franco, C.H. Montoya-Navarrete, E.J. AlzateRodríguez, H. Reyes, Determination of trihalomethanes in drinking water by solid phase microextraction- gas chromatography in Pereira, Colombia Revista Colombiana de Química, 44 (2015) 23-29.

[32] H.S. Weinberg, S.W. Krasner, S.D. Richardson, J.A.D. Thruston, The Occurrence of Disinfection By-Products (DBPs) of Health Concern in Drinking Water: Results of a Nationawide DBP Occurrence Study, National Exposure Research Laboratory, Office of Research and Development, U.S. Environmental Protection Agency, Athens, GA., (2002). [33] S. Chowdhury, Occurrences and changes of disinfection by-products in small water supply systems, Environmental Monitoring and Assessment, 190 (2017) 32.

[34] S. Chowdhury, I.R. Chowdhury, M.H. Zahir, Trihalomethanes in desalinated water: Human exposure and risk analysis, Human and Ecological Risk Assessment: An International Journal, 24 (2018) 26-48.

[35] C.H. Jeong, C. Postigo, S.D. Richardson, J.E. Simmons, S.Y. Kimura, B.J. Mariñas, D. Barcelo, P. Liang, E.D. Wagner, M.J. Plewa, Occurrence and Comparative Toxicity of Haloacetaldehyde Disinfection Byproducts in Drinking Water, Environmental Science \& Technology, 49 (2015) 13749-13759.

[36] S.W. Krasner, H.S. Weinberg, S.D. Richardson, S.J. Pastor, R. Chinn, M.J. Sclimenti, G.D. Onstad, A.D. Thruston Jr, Occurrence of a new generation of disinfection byproducts, Environmental Science and Technology, 40 (2006) 7175-7185.

[37] Y. Bichsel, U. Von Gunten, Oxidation of iodide and hypoiodous acid in the disinfection of natural waters, Environmental Science and Technology, 33 (1999) 4040-4045.

[38] Y. Bichsel, U. Von Gunten, Formation of iodo-trihalomethanes during disinfection and oxidation of iodide-containing waters, Environmental Science and Technology, 34 (2000) 2784-2791. 